\title{
Enzyme Action in the Marine Algae
}

\author{
A. R. DAVIS \\ Reprinted from AnNaxs of the Missouri Botanical \\ GARDEN 2: 771-836. November, 1915
}




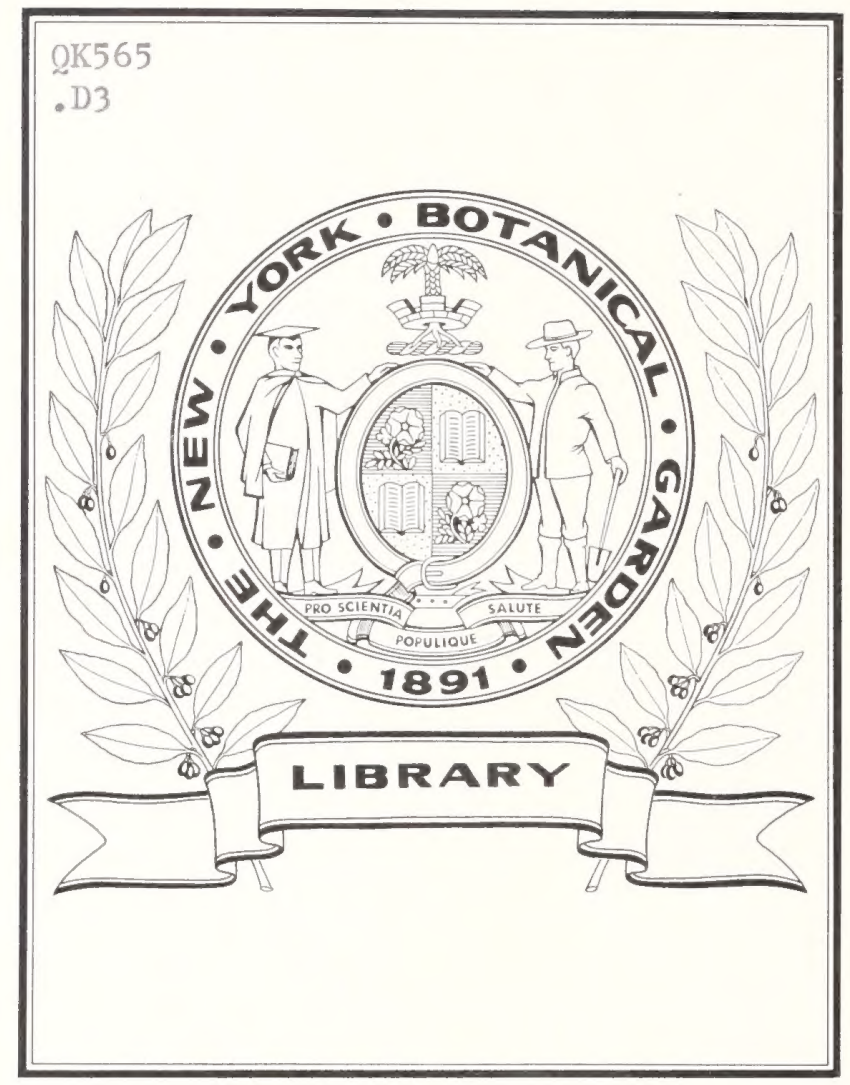








\title{
ENZYME ACTION IN THE MARINE ALGAE
}

\author{
A. R. DAVIS
}

Research Assistant to the Missouri Botanical Garden, Formerly Rufus J. Lackland Fellow in the Henry Shaw School of Botany of Washington University

In a previous contribution from this laboratory ${ }^{1}$ attention has been called to the difficulties experienced in demonstrating enzyme action in Fucus vesiculosus. Because of the negative results there obtained it was deemed worth while to extend the study to certain representative forms of the three great groups of marine algae, the "greens," the "browns," and the "reds"; first, to ascertain whether this apparent inactivity were generally characteristic of the algae, and second, because of the light such an investigation might shed upon the general metabolism of the group.

\section{Historical}

Knowledge concerning enzyme activity and the distribution of enzymes in the algae is extremely meagre. The few papers that have found their way into the literature have been, for the most part, by-products of other studies and as such have dealt merely with isolated phases of the subject. From time to time, previous to actual demonstration, the presence of enzymes has been suggested by the work of various investigators. Arber ('01), attacking the problem of carbon assimilation in Ulva latissima, ${ }^{2}$ found that the accumulation of starch in the tissue disappeared very slowly when the plant was subjected to darkness. This would suggest the presence of a diastase acting slowly. Spargo ('13) observed that Chlamydomonas began growth more slowly when the medium contained sucrose as a source of carbon than when dextrose was supplied. She suggests that the sugar is probably assim-

${ }^{1}$ Duggar, B. M. and Davis, A. R. Enzyme action in Fucus vesiculosus. Ann. Mo. Bot. Gard. 1:419-426. 1914.

${ }^{2}$ The binomials used throughout the historical review are those employsd by the original investigators, no attempt being made to have them conform to any different existing nomenclature.

AnN. Mo. Bot. Gard., Vol. 2, 1915 
ilated in the hexose form and that sucrose must be split by invertase before becoming available. It is a well-known fact that diverse fresh-water algae can be grown in pure culture on media where asparagin and peptone are sources of nitrogen. It is hardly conceivable that the large protein molecule is assimilated directly and, a priori, this would argue for the presence of both an ereptase and a desamidizing enzyme.

\section{ENZYMES FOUND IN THE MARINE ALGAE}

Few workers have demonstrated enzymes present in either the fresh- or salt-water algae. Fischer ('05), working on the storage carbohydrates of Anabaena and Oscillatoria, found that the specific carbohydrate involved, which he named anabaenin, disappeared when the algal tissue was autolysed at $40^{\circ} \mathrm{C}$. Microchemical tests showed glycogen split off. The action here, if it be due to ferments of the alga, is interesting in that the action was inhibited by .1 per cent acetic acid, by 1 per cent carbolic acid, and still more strangely, by concentrations of ethyl alcohol as low as 5 per cent. One per cent carbolic acid is quite often used as an antiseptic in enzyme experimentation, and the resistance of enzymes to even high concentrations of alcohol is common knowledge. No attempt was made to isolate the enzyme or to carry on experiments outside the cell.

Teodoresco ('12) found that Chlamydomonas in pure culture gave rise to an extracellular enzyme that decomposed sodium nucleate with the liberation of phosphorus. Later, $\left({ }^{\prime} 12^{a}\right)$ he demonstrated nucleases present in certain "bluegreens," "browns," and "reds." Unfortunately, differences in methods do not permit a true comparison of activity with that of the nuclease isolated by Dox ('10) from Penicillium camemberti, nor with that determined by Zaleski ('07) in the growing tips of Vicia faba, yet even a crude comparison is interesting. Dox added 2 grams of mold powder to $100 \mathrm{cc}$. of a 2 per cent solution of yeast nucleic acid, and maintaining his flasks at a temperature of $35-37^{\circ} \mathrm{C}$. for forty-five days, found 51 milligrams of phosphorus (calculated as phosphoric acid) liberated. Teodoresco used a .5 per cent solution of sodium 
nucleate with an unstated amount of crushed seaweed. The temperature during the incubation period varied from 21 to $26^{\circ} \mathrm{C}$. for the different forms used. The following are his results for $100 \mathrm{cc}$. of substrate:

TABLE I

\begin{tabular}{|c|c|c|}
\hline Alga & Days & $\begin{array}{c}\text { Phosphorus as } \mathrm{P}_{2} \mathrm{O}_{5} \\
\text { mgms. }\end{array}$ \\
\hline $\begin{array}{l}\text { Cladophora frusta........... } \\
\text { Ceramium rubrum.......... } \\
\text { Griffithsia setacea......... } \\
\text { Phormidium sp........... }\end{array}$ & $\begin{array}{l}57 \\
51 \\
37 \\
15\end{array}$ & $\begin{array}{l}54.3 \\
76.6 \\
62.5 \\
90.0\end{array}$ \\
\hline
\end{tabular}

Zaleski crushed growing tips of Vicia faba, added water and an antiseptic, and allowed this material to autolyse at $34^{\circ} \mathrm{C}$. for 4 days. At the end of that time the control flask showed a free phosphorus content of 13.6 milligrams and the one containing the active enzyme 51.2 milligrams. We have no means of knowing even the relative amount of enzyme present in any of these experiments and yet it seems that the algal nuclease compares very favorably with that isolated from the fungi and the higher plants.

The classes in plant physiology at the Marine Biological Laboratory, Woods Hole, for several years past have qualitatively determined diastase in Ulva lactuca. Bartholemew ('14), working on the question of starch in the Florideae, conclusively demonstrated diastase present in such "reds" as Polysiphonia variegata, Dasya elegans, Agardhiella tenera, and Ceramium sp. In order to isolate the enzyme, he used the ordinary method of precipitation by alcohol from an aqueous extract of crushed tissue. Starch as paste was hydrolysed rather slowly to an undetermined reducing sugar, presumably dextrose, 5 cc. of .25 per cent starch paste with a relatively large amount of the enzyme material requiring from 6 to 9 days for the completion of hydrolysis. Microscopic observation of the attacked starch grain showed corrosion similar to that caused by the translocation diastase of the barley. Torup (Krefting and Torup, '09) had previously isolated an enzyme from fresh Laminaria that hydrolysed the characteristic storage carbohydrate of that alga, laminarin, to dextrose. 
Atkins ('14) investigated the oxidases and peroxidases of twenty-nine diverse algae. Using guaiacum as a reagent, oxidases were demonstrated in but one-Furcellaria fastigiata -while peroxidases were shown present in seven. Alpha naphthol gave negative reactions for all the forms studied, while with it peroxidases could be determined in but twoDelesseria sanguinea and Furcellaria fastigiata. He calls attention to the reducing power of the tissues of certain algae and suggests that such agents may be responsible for the failure to obtain positive tests in the other forms. Reed ('15, '15 $)$, on the other hand, holds that many of these algae may show a specific oxidative ability. Like Atkins, he found that the ordinary reagents, such as gum guaiac, alpha naphthol, and aloin, gave negative results in all but one or two instances. When, however, alpha naphthol and para-phenylenediamine, para-phenylenediamine alone, or the hydrochlorides of these two were used in the presence of peroxide, positive tests were very generally obtained.

As earlier indicated, the results obtained by Duggar and Davis ('14) for Fucus vesiculosus were very generally negative. This was true even though a great variety of substrates were used under varying conditions, and only vigorously growing plants, fresh crushed, or dried and powdered, were employed for enzyme action. The results are exceedingly difficult to explain. It might well be that the enzymes were present but in such small amounts as to escape detection by the ordinary methods. Methods of enzyme isolation are still crude and they undoubtedly involve some loss of the ferments. Another factor suggested in the preliminary paper, was that the death of the cell might liberate certain substances which would then be free to unite with the enzyme complex, throwing it out of the sphere of action.

SOME STORAGE PRODUCTS OF THE ALGAE

It is often assumed that the presence of storage products in the plant is generally linked with the presence of specific enzymes-starch with diastase, inulin with inulase, fats with lipase, hemicelluloses with cytase, etc. These enzymes may be present at all times, as the diastase of the potato tuber and 
the diastase and maltase of the barley grain, or they may only arise when there is food transformation and translocation, as in germinating seeds. However, in the light of such possibilities of association, it is worth while to call attention briefly to some of the work that has been done on the chief storage products of the algae.

The carbohydrates have been more worked over in this respect than has any other chemical group, but much confusion still exists regarding their exact status in assimilation. Much of the study has been on the cleavage products, obtained by acid hydrolysis, of undetermined carbohydrates. These, however, are not a true index of the distribution and more restricted chemical nature of assimilable carbohydrates in the living plant; one must look rather to the work of those who have limited themselves to the isolation and determination of unaltered carbohydrates.

\section{CHLOROPHYCEAE}

Polysaccharides.-Nägeli ('63) reported "sphärokristalle", in Acetabularia which Leitgeb ('87) later showed were inulin. The former worker also demonstrated the presence of this carbohydrate in various members of the Dasycladaceae. Küster ('99) has more recently found characteristic crystal formations in Derbesia and Bryopsis which, from the many reactions they gave, appear to have been inulin. Famintzin ('67) and Krause ('70) worked on the effect of light on starch formation in Spirogyra, and within recent years, Timberlake ('01) has contributed observations on the starch of Hydrodictyon. Oltmanns ('05, p. 147) speaks of starch accumulation in the Conjugales, Volvocales, Ulotrichales, Charales, Siphonocladiales, and some of the Siphonales. He considers it the first visible product of assimilation, but thinks that it may also function as a reserve. Starch in the marine forms seems to be quite widely distributed. In the work of Arber ('01), to which reference has already been made, starch accumulation in the tissues of Ulva, Cladophora, and Enteromorpha was easily demonstrated by means of iodine. Swartz ('11) isolated starch from Ulva but was unable to prove its presence in Enteromorpha, a closely re- 
lated genus. She concluded that the carbohydrates existed in the form of hemicelluloses, probably as pentosans.

Glycogen, although frequently found in the "blue-greens," where, as held by some authors (Fischer, '05), it functions as the chief reserve carbohydrate, has been demonstrated in but one case, as far as is known, in the Chlorophyceae, and that by Beyerinck ('04) in Chlorella variegata.

Simple sugars.-The nature of the simple sugars in the group is indefinite. Klebs ('96) reported a substance in the cells of certain Heterokonteae that reduced Fehling's solution, but this means little since most algae contain noncarbohydrate reducing substances made up chiefly of tannins and tannoidal bodies. Tihomirov ('10) used the phenylhydrazine method as modified by Senft ('04) for the detection of osozone-forming sugars in algal tissues in this group, chiefly those of Codium bursa and $C$. tomentosum. After a period of thirty days, for these two forms, yellow amorphous deposits appeared in the cells indicating a sugar reaction. The definite sugars these osozones represented could not be determined, but he suggests the possibility of dextrose and d-galactose. It seems evident that they must be present in very small quantities in the tissues investigated.

\section{PHAEOPHYCEAE}

Polysaccharides.-Starch is conspicuously absent from the great group of "browns," but there are, however, certain less highly condensed polysaccharides present. Schmiedeberg ('85) speaks of a dextrin-like compound which he isolated from Laminaria. He gave to it the name "laminarin" and the general formula, $10\left(\mathrm{C}_{6} \mathrm{O}_{10} \mathrm{O}_{5}\right)-9 \mathrm{H}_{2} \mathrm{O}$. There seems, however, to be some confusion regarding his method of arriving at these figures. Torup ('09) was able to extract a dextrin from Laminaria $s p$. with warm water, that gave dextrose on hydrolysis. This could be isolated only during the winter months. He called it "kreftin." Kylin ('13), extracting crushed Laminaria saccharina, Fucus vesiculosus, and Ascophyllum nodosum, obtained a dextrin-like compound similar to that described by Schmiedeberg and he retained Schmiede- 
berg's name, "laminarin." He showed also that Torup's "kreftin" was without doubt a modification of "laminarin." Kylin ascribes to "laminarin" the same physiological function that starch performs in the higher plants, $i$. e., that of a reserve product. In a more recent paper ('15) he shows that there is an accumulation of the "laminarin" in the tissues of the algae during the summer months, while during the winter and spring this reserve is drawn upon by the young fronds until by the end of March very little of it is demonstrable.

Kylin was also able to clear up much of the confusion that has attended observation of the light-refracting granules present in the cells of many members of the group. They had been variously considered as of fatty nature, proteinaceous, tannin-like, and glucosidal. Reinke ('76) demonstrated fat-like bodies in the cells of Fucus that he looked upon as the first visible products of assimilation, a point of view later supported by Hansen ('93). Schmitz ('83) claimed two distinct bodies present, one of which, although it did not react with iodine, he called "phaeophyceenstärke," the other giving the ordinary reactions for fats. Hansteen ('92) had observed bodies in the same plant which he maintained were of carbohydrate composition and to which he applied the term, "fucosankörner." Crato ('92, '93), the same year, investigating the fat globules observed by Schmitz, suggested that they were either phloroglucin or a derivative of it, since they colored red with vanillin-hydrochloric acid. This conception was held by Bruns ('94) as well. In a later paper, Hansteen ('00) observed that the "fucosankörner" were formed in the presence of light, and this to his mind indicated that they function as the first assimilable products. Hunger's ('02) work two years later pointed to Hansteen's "fucosankörner" as being glucosidal in nature, the carbohydrate attached being bound up with phloroglucin, or at times, with tannic acid. Some of the larger "körner" gave fat reactions, some protein. Kylin found three definite bodies in the cell, the nature of which had been confused by earlier workersfat globules, proteinaceous particles, and tannin-like bodiesthese latter probably representing the "fucosankörner" of 
Hansteen. He holds that none of these are to be considered the first visible products of assimilation, and suggests that here, as in most phanerogams, carbohydrates function in that rôle.

Simple sugars.-As far as is known, Tihomirov ('10) was the first to definitely demonstrate simple sugars in these plants. He used the same phenylhydrazine method employed with the "greens," but as was the case there, was unable to connect the osozones with definite sugars. The osozones took considerable periods of time to form, in some cases as long as five months, evidence pointing to the low concentration of sugars in the cell. It is a question, too, whether during this long period of incubation some of the more highly condensed carbohydrates in the cell were not hydrolysed far enough to give the sugar tests. Using the same method, Kylin ('13) was unable to substantiate these results. However, by using 40 per cent alcohol as an extracting agent, precipitating the inorganic material with lead acetate, and then purifying with alcohol, he was able to obtain reducing sugars from several of the Fucoideae, particularly Laminaria digitata, L. saccharina, Ascophyllum nodosum, and Fucus vesiculosus. In all cases Seliwanoff's test for fructose was positive, while dextrose was demonstrated by its osozone. These sugars he considers the first products of assimilation referred to above.

\section{RHODOPHYCEAE}

Polysaccharides.-The so-called Florideae-starch has been the source of many investigations, from the time of Nägeli ('58) and Van Tieghem ('65) to the present day. Although not identical perhaps, it is very similar to the starch of the higher plants, and as very generally held, it undoubtedly functions in the same manner. Meyer ('95), Kolkwitz ('00), and Bartholemew ('14) hold the opinion that it represents a combination between true starch and dextrin, while Bütschli ('03) suggests the possibility of its being a transitional stage between amyloporphyrin and amyloerythrin. Kylin ('13) considers it as standing midway between starch and dextrin. This investigator succeeded in isolating 
Florideae-starch from Furcellaria fastigiata, that was readily hydrolysed to dextrose by malt diastase, and it will be remembered that Bartholemew ('14) isolated diastase from several of the "reds" that split phanerogamic starch to reducing sugars.

Simple sugars.-Very little work has been done on the diand monosaccharides of the "reds." Tihomirov ('10) succeeded in obtaining the same yellow amorphous osozone deposits in the tissues of Sphaerococcus crispus and Gigartina mamillosa that he had in certain members of the "greens" and "browns," but here, as in the other groups, the specific osozone involved could not be determined.

\section{FATS AS STORAGE PRODUCTS}

Many observations have made it evident that fats in some form or other are generally present in the algae, their peculiar rôle, however, having been very little investigated. In some of the siphonaceous forms, particularly Vaucheria, they seem to replace carbohydrates. Whether fats are to be regarded as the first visible products of assimilation in these forms is disputed. Some workers hold them to be reserve products, some by-products of metabolism. If they are utilized as a reserve or storage product in any of the forms, one might expect to find evidences of lipolytic action, yet none has been reported so far.

As stated by Czapek ('13, p. 761), Loew and Bokorny find that Spirogyra and other filamentous forms contain 6 to 9 per cent of the dry weight as fat. This probably includes lecithin. The same authority gives the following results as obtained by Sestini, the figures being percentages of the dry weight:

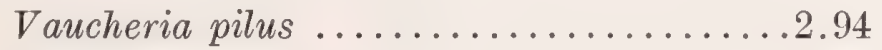

Ulva latissima .....................21

Fucus vesiculosus ...................67

Valonia aegagropila ..................15

Gracilaria confervoides ................11

König and Bettels ('05) made a large number of analyses of the dry tissues of a variety of marine algae and found a fat 
content ranging from .20 per cent in Enteromorpha to .98 per cent in Porphyra.

\section{RELATION OF THE ALGAE TO NITROGEN}

Some of the recent work on pure culture methods with fresh-water algae, such as that of Beyerinck ('90), Charpentier ('03, '03'), Chick ('03), Artari ('13), Spargo ('13), and Schramm ('14) have conclusively proved that these forms can utilize organic nitrogen. Furthermore, the work of Letts and Hawthorne ('11), and Foster ('14) point to the fact that the marine forms may have this capacity as well. Letts and Hawthorne and also Letts and Richards ('11) showed that Ulva latissima grew better in sewage-contaminated sea-water than in water from the open sea. Foster placed strips of Ulva lactuca in normal and artificial sea-water, containing in addition compounds of nitrogen in varying concentrations. When urea or ammonium sulphate was added to either solution an accelerated growth took place.

The current conception concerning the assimilation of organic nitrogen by the animal organism is that the protein and amino acid molecule must be completely desamidized before the building-up process can begin. In the absence of definite information to the contrary, we can conceive of a parallel situation existing in the plant. The question at once arises in regard to the algae, whether this be due to the agency of amidases formed by the tissue, or to the activity of desamidizing bacteria, the presence of which Brandt ('99), Gran ('02), Baur ('02), Reinke ('03), Benecke and Keutner ('03), and others have shown to exist abundantly in harbor waters. Neither Letts and Hawthorne nor Foster worked with pure cultures, and these bacteria may have been the agency in their experiments to render the amino-nitrogen assimilable.

\section{CARBOHYDRATES AND CARBOHYDRATE CLEAVAGE PRODUCTS OF ALGAL SLIME}

Besides the carbohydrates that may be directly assimilable, we find those whose function in metabolism is more or less disputed. The so-called algal slime is made up chiefly of such products. 
Chemical composition.-Greenish ('81) found agar from Fucus amylaceus to consist of 37.21 per cent gelose (probably galactan since it passed to galactose on hydrolysis) and that from Sphaerococcus crispus of 60 per cent of the same carbohydrate. König and Bettels ('05) give the carbohydrate composition of agar-agar from Gelidium as 33 per cent galactans and 3.1 per cent pentosans; by hydrolysis, d-galactose and levulinic acid were split off. Günther and Tollens ('90) found fucosan in Fucus from which the methyl-pentose, fucose, was split off. Galactose was also demonstrated. Sebor ('00) obtained galactose, glucose, and fructose from the slime of Chondrus crispus by acid hydrolysis. He held that the slime is a very complex carbohydrate of high molecular weight, made up chiefly of galactosan, glucosan, and fructosan.

The cleavage products of Porphyra laciniata, as investigated by Oshima and Tollens ('01), were found to consist chiefly of l-galactose and mannose, but glucose, fucose, and other pentoses were also obtained. Müther and Tollens ('04) found methyl-pentosans in several of the Fucaceae. König and Bettels ('05), working on the carbohydrate hydrolytic products of various species of Porphyra, Gelidium, Laminaria, Cystophyllum, and Enteromorpha, found them to consist of such hexoses as galactose, dextrose, and fructose, as well as several pentoses, chiefly methyl-pentoses. Enteromorpha yielded a pentose-rhamnose. The results of Swartz ('11) agree with those above, namely, that for all forms studied, representatives of the "'greens," "browns," and "reds," pentosans were always present, and galactans frequently so. Kylin ('13), by direct extraction with warm water of crushed Ceramium, Furcellaria, and Dumotia, obtained substances that gave the mucic acid test for galactose, as well as the phloroglucin test for pentosans. Substances giving pentosan reactions alone were isolated from the slime of Ascophyllum nodosum, Fucus vesiculosus, and Laminaria sp. $\mathrm{He}$ was apparently unable to substantiate the finding of galactan in Fucus by Günther and Tollens, and this negative result also conflicts with the statement of Swartz, who says that the gelatinization in the algae is due to the galactan groups. 
Kylin ('14) and others have also demonstrated pectin-like compounds forming the middle lamella in various members of the Fraceae. These exist as the calcium salts of pectic-like acids which Kylin designates "Fucinsäure" and "Alginsäure."

PHYSIOLOGICAL SIGNIFICANCE OF ALGAL SLIME

It is seen that algal slime is made up chiefly of the anhydrides of hexoses and pentoses-carbohydrates that must be broken down to simpler form before assimilation by the plant would be possible. 'Two questions naturally arise: (1) Do the algae concerned form enzymes that will hydrolyse these highly condensed carbohydrates to assimilable form? Does the slime itself arise through the breaking down of the hemicelluloses of the cell wall through enzymic or other causes, or does it represent a final stage in the condensation of those hemicelluloses?

Algal slime as a reserve product.-Galactanases and mannases have been demonstrated in the phanerogams and in the fungi by Bourquelot and Hérissey ('99), Grüss ('02), and Hérissey ('03). The last worker especially has clearly shown the distinct rôle that galactans and mannans may play as reserve products in the tubers of the Orchidaceae and in many of the Leguminoseae. It is significant that Gran ('02a) was able to isolate a marine bacillus, $B$. gelaticus, that acted on part of the constituents of agar-agar to give a reducing sugar. From the standpoint of a possible symbiosis it would be interesting to know if this organism has the ability to fix free nitrogen. Saiki ('06) experimented with a number of algal and lichen preparations containing a large proportion of carbohydrates as galactans and pentosans, and concluded that the latter could not be transformed into sugars readily by carbohydrate digesting enzymes of animal origin and scarcely more so by the vegetable enzymes, either of the higher plants or of bacteria.

Still less is known of the digestion of pentosans by the higher plants. Schöne and Tollens ('92) found no decrease in the amount of pentosans during germination and conclude 
that they cannot function as reserves. Cross, Bevan, and Smith ('95) consider the pentosans as by-products of metabolism and once formed remain unalterable. Ravenna and Cereser ('09), on the other hand, in some very interesting experiments, found that when dextrose was supplied as the sole nutrient to the leaves, pentosans increased greatly, especially in the light. If, however, the function of chlorophyll is inhibited, a decrease in the amount of pentosans takes place. These results form the basis for their conclusion that pentosans may sometimes function as reserves.

The origin of algal slime.-The question concerning the origin of the slimy and gummy constituents of cells, whether they arise through enzyme action or through other causes, has provoked much discussion. There is considerable doubt whether such gums can arise directly from true cellulose or whether they are, at least in the case of the plant mucilages, laid down as such.

One might roughly group the plant gums into those arising as a result of some external excitant, such as, for example, cherry gum, acacia gum, gums of citrus, etc., and those which seem to be normal constituents of the plant, as the mucilages found in the epidermis of many seeds and plant organs. The former arise as a result of a pathological condition; the latter, as far as we know, are normal physiological products and as such are more nearly comparable to the algal slime.

Klebs ('84), investigating slime formation in some of the lower algae, particularly some of the Desmidiaceae, held that it was not a conversion product of cellulose. Hauptfleisch ('88) substantiated the conclusion of Klebs, and going further, states that it arises in this particular case through the activity of the protoplasm, being excreted through pores. Oltmanns ('04, p. 76) illustrates very clearly the arrangement of these pores. Tschirsch ('89) differentiates these slimes or mucilages into those giving a cellulose reaction and those not doing so, the former having some relation perhaps to the cellulose, but the latter being laid down on the cell wall as such by the protoplasm. He holds the epidermal slime of Spirogyra to be of this latter type, which he calls "echter Schleim." In 
the same work the author concludes the slime of the Fucaceae and of the Florideae to be of the "echter" type, occurring here, however, not as a layer laid down on the inner cell wall, but as an intercellular substance. Guignard ('93) held much the same view, and in an excellent histological investigation, clearly demonstrated the presence of slime or mucilage ducts in the Laminariaceae.

Mucilages very similar in nature and origin to the algal slimes occur in the higher plants, and much more work has been done with them than with those occurring in the algae. It is hardly necessary to go into the historical aspect of this phase of the work. The current conception of its origin is voiced by Walliczek ('93), who, investigating rather fully the location of different types of normal mucilages by means of suitable stains, found that in almost all cases they were laid down as such. According to him, the slime forms secondary layers on the cell wall which he designates "Membranverdickungsschichten"-layers that in many instances almost completely fill the cell. Where the epidermal layer of seeds becomes gelatinous, as, for example, in those of flax, mistletoe, various Cruciferae, etc., it is this inner cell wall which Walliczek holds to be the seat of slime formation. Upon contact with water the slime swells remarkably, filling the cell and at times even bursting it. There may or may not be an actual hydrolysis of the true cellulose, but if there is it seems rarely to enter into mucilage formation.

\section{Experimental}

Forms used.-The algae to be used for enzyme investigation were collected in the vicinity of Woods Hole, Massachusetts, during the summers of 1913-14, at which time the plants were also dried for winter work at the Missouri Botanical Garden. Work with the fresh tissue was carried on at the Marine Biological Laboratory, Woods Hole, during the latter summer. The selection of forms with which to work was limited to those relatively abundant in the neighboring waters, a further limiting factor in selection being relative freedom from adhering marine organisms. Only those plants 
were selected that were "clean." This was an important precaution, since many adhering organisms have been found to be quite active enzymatically, and the presence of even a few might well lead to serious errors in the final results. The following forms lent themselves most readily to the work: ${ }^{1}$

Chlorophyceae

Ulva lactuca (L.) Le Jolis

Enteromorpha intestinalis (L.) Link

Phaeophyceae

Laminaria Agardhii Kjellm.

Ascophyllum nodosum (L.) Le Jolis

Mesogloea divaricata (Ag.) Kutz

Rhodophyceae

Ceramium rubrum (Huds.) Ag. Agardhiella tenera (J. Ag.) Schmitz

Rhodymenia palmata (L.) Grev.

Chondrus crispus (L.) Stack.

Preparation of algal material.-In addition to the question of cleanliness, great care was taken to select only plants that were in a young, vigorously growing condition. These were brought into the laboratory, placed in large aquarium jars containing salt water, picked over, and all detectable foreign matter removed. A thorough washing in running salt water for two hours was then given, after which, with the exception of one or two forms that rapidly gelatinized, the plants were placed in running fresh water for 10 or 15 minutes. This fresh water treatment was very efficacious in causing small snails and other minute marine organisms to loosen their hold.

The plants so washed were either crushed and used at once with the substrate for enzyme action, or they were dried for future use. In either case, two general ways of using the ma-

${ }^{1}$ With the exception of Laminaria Agardhii and Agardhiella tenera, these binomials conform to the nomenclature as given by Farlow (Marine algae of New England, pp. 1-210. $p l .1-14.1881)$; these two forms are as given by De Toni (Sylloge Algarum 3: p. 349. 1895) and Engler and Prantl (Nat. Pflanzenfam. $1^{2}: 371.1896$ ), respectively. 
terial for such action were employed. The tissue was added directly to the substrate, or it was extracted with water by the method to be described later and a water-diffusion used of the alcohol precipitate. If the fresh tissue were to be used directly, it was ground in a meat chopper two or three times, then pounded in a large mortar with an equal amount of fine, clean, quartz sand. This treatment gave a very homogeneous pulp, one in which a large number of the cells were broken down. If desired for future use, the plants were either dried at room temperature or dehydrated by the following modified Buchner "dauerhefe" process:

3 volumes 95 per cent alcohol for 15 minutes.
3 volumes acetone 15 minutes.
3 volumes 95 per cent alcohol for 10 minutes.
3 volumes acetone
2 volumes absolute alcohol

$$
\text { or ether for } 5 \text { minutes. }
$$

After each treatment, the dehydrating liquid was pressed out through two thicknesses of cheese cloth by making a tourniquet. Upon the removal of the absolute alcohol or ether, the tissue was spread out on adsorbent paper, either filter paper or paper toweling, until all the dehydrating agent hat evaporated. A uniformly dry, brittle, easily crushed material usually resulted that was roughly broken up and stored in tightly stoppered bottles for future use. Those plants that were dried at room temperature were simply wrapped in paper or placed in paper bags until needed.

The crushing of the dry material was accomplished in the same mauner as was the fresh. Usually it was ground twice or more in an ordinary meal mill, then pounded in a mortar with an equal weight of quartz sand until a very fine powder was obtained. The sand was dispensed with if the tissue were easily crushed.

Methods of isolating the enzymes.-As indicated above, there were two general methods of using the material for enzyme action: first, adding the crushed tissue directly to the substrate, either as fresh pulp or as "dauerhefe" powder; 
second, by extracting the tissue with water and precipitating the protein-enzyme complex with several volumes of 95 per cent alcohol. Wherever possible the first method was used, since it was thought that in this way the maximum enzymic activity would be obtained. However, the fresh pulp and the powdered material contained a substance, or substances (probably tannoidal bodies), that reduced copper from Fehling's solution, and so in all experiments where sugar determinations were involved, it was found necessary to use the extraction and precipitation method; by this means all the unknown reducing substances were avoided. The method was as follows:

To a known amount of the crushed, fresh algal material, $3-5$ volumes by weight of distilled water were added; to the powdered tissue, 8-10 volumes. The amounts varied owing to the differences in viscosity produced by the different algae. In some forms a relatively large amount of water was necessary in order to overcome difficulties in handling due to this high viscosity. Two per cent toluene was generally added as an antiseptic, or in some cases, 1 per cent chloroform-thymol mixture was used (5 per cent thymol dissolved in chloroform), and the extraction allowed to go for 12 hours at room temperature, or for 4 hours at $35^{\circ} \mathrm{C}$. The water extract, if at all viscous, was then filtered off through two thicknesses of cheese cloth and the algal tissue pressed out as completely as possible by making a tourniquet of the cloth. Filtering through cotton was tried at first, both with pressure and without, but the method had the disadvantage of slowness and also that of adsorption by the cotton. Neither did filter paper lend itself efficiently to the filtration of such viscous liquids, a drier residue being obtainable in a shorter time by the cheese cloth-tourniquet method. A press would have been desirable but none was at hand. If the medium were not viscous, it was filtered with pressure through a thin layer of cotton or a coarse filter paper in the bottom of a Buchner funnel.

The protein-enzyme complex was precipitated with 3 volumes of 95 per cent alcohol. After a few moments the 
coagulum either came to the top or settled to the bottom of the vessel-if to the top, it was usually very much aggregated and little difficulty was experienced in the filtering, if to the bottom, it was generally in a very finely divided condition and unless care was exercised in the decantation of the supernatant liquid the pores of the filter soon became clogged, resulting in extremely slow filtration. Time was therefore given for a complete settling out ( 15 minutes to half an hour sufficed) and all the clear fluid filtered off before the coagulum reached the filter paper.

A homogeneous diffusion of the precipitate was made by placing the filter paper with the attached coagulum in a known volume of distilled water. The paper could soon be removed without loss of material, and the weight of the original fresh or dry tissue represented by an aliquot portion of the solution easily reckoned. If the precipitate were not required immediately, it was dried on a filter paper at room temperature and stored in stoppered jars. In none of the experiments was the enzyme material purified further.

When dissolved in water, the precipitates behaved differently. Some, especially those where much slime had been noticed in the extraction, gave an extremely viscous suspension, others a suspension of low viscosity. In Laminaria and Chondrus, where the extract had been quite viscous and slimy, the protein was caught up in the precipitated slime in such a way as to make the freeing of it practically impossible. The precipitate in these cases was very large and when diffused in water gave a suspension difficult to handle. Rhodymenia, Ceramium, and Enteromorpha, on the other hand, gave a finely divided precipitate that produced no viscosity.

Glassware, antiseptics, solutions, etc.-With few exceptions, the various experiments were set up in 125 cc. Erlenmeyer flasks. All glassware was thoroughly cleaned with strong soap and then with chromic-sulphuric cleaning mixture, after which it was rinsed several times with tap and distilled water.

Solutions were made up from either Merck's or Kahlbaum's "guarantiert" chemicals. 
Three general antiseptics were used-toluene, alcohol to 20 per cent, and 5 per cent thymol in chloroform. Toluene was, in general, the most satisfactory. Usually it was used to 2 per cent concentration, but where large surfaces were exposed, as high as 4 per cent was found necessary. The chloroformthymol was also very efficacious, but in the carbohydrate experiments chloroform could not be used because of its power of reducing copper. In the lipase work the substrate was made up to 20 per cent alcohol since the action seemed to proceed best in the presence of this antiseptic. In all cases where the experiments were maintained over a considerable period of time, it was necessary to add additional antiseptic from time to time.

Checks were set up in all experiments-on the substrate, on the material used to demonstrate enzyme action, and on the substrate plus such enzyme material boiled to destroy any ferments that might be present.

\section{CARBOHYDRASES OF THE ALGAE}

In these experiments the alcohol precipitate from an aqueous extract of crushed, fresh or dried, algal tissue was employed as an enzyme source, this precipitate being diffused in such a volume of distilled water that one gram of the original material was represented by 5 cc. of the diffusion. Thus one can more closely compare the amounts of enzyme present in definite amounts of different algal tissue. The number of cubic centimeters of diffusion will be noted in connection with each set of experiments.

Substrates.-Starch, dextrin, inulin, sucrose, maltose, lactose, glycogen, and in one or two cases, laminarin isolated from Laminaria Agardhii, were used as substrates. These were made up in 1 per cent concentrations with the exceptions of maltose and glycogen, where .25 per cent, and laminarin, where .5 per cent concentrations were employed.

Of the many suggested methods for making up starch paste, the following one used by Clark ('11) was found to give the best satisfaction. Ten grams of potato starch were weighed out and placed in a beaker with 250-300 cc. of distilled water. 
This was brought to a boil with constant stirring, and when an opalescent solution resulted the paste was transferred with rinsing to a 2-liter flask containing about 500 cc. of boiling water. The lot was boiled under a reflux condenser for two hours, cooled, and made up to a liter. Although, as is stated by Clark, this treatment is very effective in breaking down the starch grain physically, no detectable hydrolysis takes place, and the additional advantage is gained in obtaining a paste that will not settle out, even after long standing. Two per cent toluene was employed as an antiseptic if the starch were not to be used immediately.

Since all dextrin obtainable contained some reducing sugar, it was found necessary to purify it by making a concentrated solution in hot distilled water, and then precipitating out with several volumes of 95 per cent alcohol. The dextrin was caught on a filter paper and dried at a low constant temperature.

Laminarin, a dextrin-like carbohydrate found in many of the Fucaceae, was isolated from Laminaria Agardhii according to the method employed by Kylin ('13), with some few slight modifications. Freshly collected Laminaria was crushed in the usual way and 1,680 grams of the pulp were boiled with 7 liters of water for 24 hours, water being added from time to time to replace that lost through evaporation. The extract was then filtered off through a double thickness of cheese cloth, and the residue pressed out with a tourniquet. About 3,000 ce. of a dirty brown filtrate were obtained which was divided into three lots of 1,000 ce. each. To the first of these was added a concentrated $\mathrm{Ba}(\mathrm{OH})_{2}$ solution until the precipitation of the inorganic matter was complete. The precipitate was caught on a cotton filter in a Buchner funnel, the filtrate being a clear, golden-colored liquid. The inorganic material in the other two lots was precipitated with basic lead acetate, the liquid filtered off through cotton, and the excess of lead removed with $\mathrm{H}_{2} \mathrm{~S}$. The solutions were filtered while hot through double filter paper to remove the lead sulphide, and then the excess of $\mathrm{H}_{2} \mathrm{~S}$ was driven off with heat. The three portions were first evaporated to about one- 
third their volume, when the scum that formed was filtered off; this filtrate was then further evaporated to about onefifth the original volume on the water bath. At this point the two lead acetate portions were placed together. Ninetyfive per cent alcohol was added to each of the lots to about 80 per cent concentration when a flocculent precipitate came down rather slowly. With the $\mathrm{Ba}(\mathrm{OH})_{2}$ portion this was copious, with the lead acetate, slight. After two hours the precipitates were filtered off, washed with absolute alcohol, redissolved in a small amount of distilled water, and then reprecipitated with 4 volumes of absolute alcohol, the resulting precipitate being dried over $\mathrm{CaCl}_{2}$. From the $\mathrm{Ba}(\mathrm{OH})_{2}$ portion, 4.2 grams of a creamy white powder were obtained that gave a very slightly reddish tinge with iodine, did not reduce Fehling's, and was easily soluble in water, giving a clear solution. Upon hydrolysis with weak $\mathrm{H}_{2} \mathrm{SO}_{4}$ a reducing sugar was split off. The lead acetate portion gave but two grams of the same material. This powder was taken to be the laminarin described by Kylin.

The determination of reducing sugars.-The reduction of copper, or in the case of maltose and lactose, the increase in the reducing value of the substrate plus the enzyme over that of the checks, was taken as the measure of carbohydrate hydrolysis. In this determination the permanganate titration method, as modified and described by Shaffer ('14), was used, it being possible with it to determine amounts of sugars as low as 2 milligrams ${ }^{1}$ very accurately and quickly. Shaffer's description may not be generally available to plant workers who may desire to use this really splendid method, and so the various steps in the process as used here are set down in some detail.

Ten cc. of the carbohydrate-enzyme substrate were placed in a large test-tube containing 5 cc. of water, and just brought to a boil. At this point a drop of 50 per cent acetic acid was added. When the slight protein precipitate formed, 5 cc. of

1 Shaffer determines values below two milligrams, but as used here, consistent results could not be obtained where less than that amount was involved. Below this point the relative increase in the experimental error is large. 
colloidal iron (Iron dialysed, Merck) were pipetted in and the tube well shaken, the iron then being flocked out with $.25 \mathrm{gram}$ of $\mathrm{Na}_{2} \mathrm{SO}_{4}$. Upon the addition of this latter the mixture was again thoroughly shaken and the iron precipitate thrown down by centrifuging, the resulting clear, supernatant liquid then being decanted off through a small filter. This filtrate was entirely free of proteins or other substances which, through oxidation later, would lead to errors in the permanganate values. Ten cc. of this filtrate were placed in a 50 cc. lipped centrifuge tube, and standard Fehling's solution added, the copper content of which was in excess of that reducible by the sugar present. ${ }^{1}$ The tube was then placed in a boiling water bath for 10 minutes, at the end of which time it was centrifuged at a moderate speed for 2 minutes, the supernatant unreduced Fehling's carefully decanted off, a like volume of distilled water added, and the cuprous oxide again thrown down by a 2 -minute centrifuging. All but 1 or 2 ce. of this wash water was carefully decanted off, and the copper dissolved in the smallest amount necessary of a mixture of equal parts of 10 per cent ammonium ferric sulphate and 50 per cent sulphuric acid. It was found that if the copper were stirred up with a glass rod just before dissolving, it went into solution more readily. The dissolved copper was titrated directly in the centrifuge tube against $\mathrm{N} / 50 \mathrm{KMnO}_{4}{ }^{2}$

By calculation it is found that 1 ce. of $\mathrm{N} / 50 \mathrm{KMnO}_{4}$ is equivalent to 1.27 milligrams of copper, and for the conversion of this into glucose use was made of the table prepared by Shaffer. ${ }^{3}$

As stated by Shaffer, care must be observed on the three following points: (1) to eliminate all oxidizable substances other than sugar, (2) to titrate the cuprous oxide immediately after dissolving, (3) to use poor conductors of heat as containers of the centrifuge tubes in the water bath, else many broken tubes will result. As employed here, circular wire

\footnotetext{
${ }^{1}$ In the determinations made here this amount never exceeded 10 cc.

${ }^{2}$ It is necessary to titrate immediately after dissolving because of the danger of oxidation of the cuprous oxide. If larger amounts of sugar are concerned, $\mathrm{N} / 10 \mathrm{KMnO}_{4}$ may be used.
} 
baskets having wooden bottoms and tops were used, the tops containing holes large enough for the free insertion of the centrifuge tubes, and the bottoms, slight depressions into which the tubes might rest. It is always necessary to run blanks with Fehling's solution since some reduction always takes place. The cuprous oxide solvent must be free from ferrous iron, and this can be assured by the addition of a trace of permanganate.

Method of setting up experiments.-Fifty cc. of the substrate to be used were placed in 125 cc. Erlenmeyer flasks with 2 per cent toluene as an antiseptic. If the series were maintained longer than six weeks, another 2 per cent toluene was added. As previously noted, in these carbohydrate experiments the material used for enzyme action was an alcohol precipitate from a water extract of algal powder or pulp. This was diffused in water so that $10 \mathrm{cc}$. of the diffusion represented 2 grams of the original tissue. Usually this amount was added to the substrate to be tested. Duplicates and checks were set up in accordance with the following model series for starch:

1. 50 cc. starch, 10 cc. enzyme diffusion.

2. 50 ce. starch, 10 cc. enzyme diffusion.

3. 50 cc. starch, 10 cc. boiled enzyme diffusion.

4. 50 cc. starch, 10 cc. boiled enzyme diffusion.

5. 50 cc. starch, 10 cc. distilled water.

6. 50 cc. starch, 10 ce. distilled water.

s To make this table more generally available, it is printed here in full.

Shaffer's table of copper-glucose equivalents

$\begin{array}{cccccc}\begin{array}{c}\text { mgms. } \\ \text { copper }\end{array} & \begin{array}{c}\text { mgms. } \\ \text { glucose }\end{array} & \begin{array}{c}\text { mgms. } \\ \text { copper }\end{array} & \begin{array}{c}\text { mgms. } \\ \text { glucose }\end{array} & \begin{array}{c}\text { mgms. } \\ \text { copper }\end{array} & \begin{array}{c}\text { mgms. } \\ \text { glucose }\end{array} \\ 0.7 & .47 & 6.0 & 2.74 & 20.0 & 9.71 \\ 1.0 & .62 & 7.0 & 3.21 & 25.0 & 12.25 \\ 1.5 & .88 & 8.0 & 3.68 & 30.0 & 14.80 \\ 2.0 & 1.11 & 9.0 & 4.15 & 35.0 & 17.40 \\ 2.5 & 1.32 & 10.0 & 4.65 & 40.0 & 20.00 \\ 3.0 & 1.50 & 12.0 & \mathbf{5 . 6 1} & 50.0 & 25.00 \\ 3.5 & 1.67 & 14.0 & 6.61 & 60.0 & 30.10 \\ 4.0 & 1.82 & 16.0 & 7.61 & 80.0 & 40.40 \\ 5.0 & 2.27 & 18.0 & 8.65 & 100.0 & 50.70\end{array}$


In addition, at the end of a complete carbohydrate series there were included for each alga the following checks:

1. 50 cc. distilled water, 10 cc. enzyme diffusion.

2. 50 cc. distilled water, 10 cc. enzyme diffusion.

3. 50 cc. distilled water, 10 cc. boiled enzyme diffusion.

4. 50 cc. distilled water, $10 \mathrm{cc}$. boiled enzyme diffusion.

Where the enzyme diffusion referred to above actually contained carbohydrases, it was extremely difficult to render them inactive by heating-10 minutes at the boiling point not being sufficient in most cases to more than slow down the action. This was probably due to the impurities contained, the relatively large amounts of protein and slime present tending to protect the enzymes. Those extracts relatively richer in such constituents proved the more difficult to render inactive. The expedient was finally adopted of placing the enzyme material in the autoclave and bringing the pressure in the latter up to 15 pounds. This proved quite effective.

\section{THE CARBOHYDRASES OF ULVA LACTUCA}

The effect of an extract of Ulva lactuca on different starches. - Since starches were to be used in many of the following

TABLE II

THE ACTION OF ULVA LACTUCA "DIFFUSION-EXTRACT"* UPON CERTAIN STARCHES

\begin{tabular}{|c|c|c|c|c|}
\hline \multirow[b]{2}{*}{$\begin{array}{l}\text { Starch } \\
50 \text { cc. } \\
1 \text { per cent }\end{array}$} & \multicolumn{2}{|c|}{15 days } & \multicolumn{2}{|r|}{30 days } \\
\hline & $\begin{array}{l}\text { Sugar as } \\
\text { glucose } \\
\text { in } 5 \mathrm{cc} . \dagger \\
\text { mgms. }\end{array}$ & Iodine test & $\begin{array}{l}\text { Sugar as } \\
\text { glucose } \\
\text { in } 5 \mathrm{cc} \text {. } \\
\text { mgms. }\end{array}$ & Iodine test \\
\hline 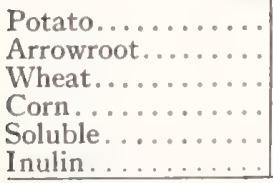 & $\begin{array}{r}10.1 \\
9.8 \\
9.9 \\
6.3 \\
8.7 \\
\end{array}$ & $\begin{array}{l}\text { Blue, trace red } \\
\text { Blue, trace red } \\
\text { Blue, trace red } \\
\text { Blue } \\
\text { Blue } \\
\ldots \ldots \ldots \ldots\end{array}$ & $\begin{array}{l}17.4 \\
16.9 \\
17.1 \\
10.8 \\
15.9 \\
\text { Trace } \$\end{array}$ & $\begin{array}{l}\text { Complete hydrolysis } \\
\text { Complete hydrolysis } \\
\text { Complete hydrolysis } \\
\text { Reddish purple } \\
\text { Traces dextrin } \\
\text {............................. }\end{array}$ \\
\hline
\end{tabular}

*Wherever the term "diffusion-extract" is employed, it refers to a diffusion in water of the alcohol precipitate from an aqueous extract of the alga under discussion.

† The sugar values in this and the following tables are net, i. e., sugar values for all checks have been deducted.

* In all the following experiments an amount of sugar below $2 \mathrm{mgms}$. is designated a "trace." 
experiments, it was desired to know which, if any, were the most favorable substrates for the diastases of the algae. The action of diastase from Ulva lactuca was taken as an index. Potato, arrowroot, wheat, corn, and soluble starch, as well as inulin, were made up in 1 per cent concentrations in the manner previously described. To $50 \mathrm{cc}$. of each of these substrates were added 10 cc. of a diffusion of an alcohol precipitate from a water extract of dehydrated Ulva lactuca. Two per cent toluene was added as an antiseptic, and the flasks maintained at a temperature of $35^{\circ} \mathrm{C}$. for 30 days. The results of the experiments are given in table Ir.

The data show but slight differences in the rate of digestion of the starches with the exception of corn starch, and the reason for this is not clear. One would expect it to be due to some impurity in the starch rather than to an inherent difference in the granule. The action on inulin was so slight as not to warrant the assumption of hydrolysis due to inulase.

The action of an extract of Ulva lactuca upon various carbohydrates.-A series was arranged using a "diffusionextract" from Ulva lactuca with the following substrates: potato starch, dextrin, glycogen, sucrose, maltose, and lactose. Ten cc. of the "diffusion-extract" were added to each flask with 50 cc. of substrate, 2 per cent toluene used as an antiseptic, and the flasks maintained at a temperature of $35^{\circ} \mathrm{C}$. for 30 days. The data are given in table III.

TABLE III

THE ACTION OF AN EXTRACT OF ULVA LACTUCA UPON VARIOUS CARBOHYDRATES

\begin{tabular}{|c|c|c|}
\hline \multirow{2}{*}{ Substrate } & \multicolumn{2}{|c|}{$\begin{array}{c}\text { Sugar as glucose in } 5 \text { cc. } \\
\text { mgms. }\end{array}$} \\
\hline & 15 days & 30 days \\
\hline 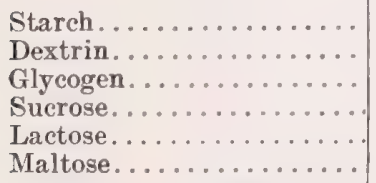 & $\begin{array}{r}10.20 \\
6.30 \\
2.25 \\
\cdots \\
\cdots\end{array}$ & $\begin{array}{r}15.50 \\
9.95 \\
3.50 \\
\text { Trace } \\
\text { Trace }\end{array}$ \\
\hline
\end{tabular}

The two polysaccharides, starch and dextrin, are very readily attacked even though the action is slow. Glycogen, which is hydrolysed by most diastatic enzymes with about the 
same ease as starch, seems very slightly acted upon by the carbohydrases of Ulva. The failure of action on sucrose and lactose is not so surprising as is that on maltose, for one would expect the action on polysaccharides to continue to what is generally held to be directly assimilable sugars, i. e., the hexoses.

THE CARBOHYDRASES OF ENTEROMORPHA INTESTINALIS

This series (table Iv) was run under exactly the same conditions as the one preceding. The "diffusion-extract" was from dehydrated tissue about two months old. Ten cc. of this were used with each 50 cc. of substrate, toluene added as an antiseptic, and the flasks kept at a temperature of $35^{\circ} \mathrm{C}$. for 30 days.

TABLE IV

THEACTION OF A "DIFFUSION-EXTRACT" FROM AIR-DRIED ENTEROMORPHA TISSUE UPON CERTAIN CARBOHYDRATES

\begin{tabular}{|c|c|c|}
\hline \multirow{2}{*}{ Substrate } & \multicolumn{2}{|c|}{$\begin{array}{c}\text { Sugar as glucose in } 5 \text { cc. } \\
\text { mgms. }\end{array}$} \\
\hline & 15 days & 30 days \\
\hline 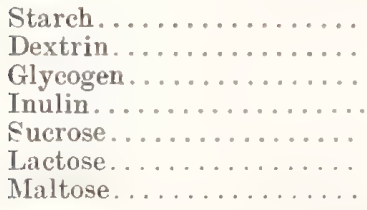 & $\begin{array}{l}9.7 \\
5.1 \\
2.8 \\
\text { Trace } \\
\cdots \\
\cdots \\
\cdots\end{array}$ & $\begin{array}{r}13.1 \\
9.8 \\
3.9 \\
\text { Trace } \\
\text { Trace } \\
\cdots \\
\cdots\end{array}$ \\
\hline
\end{tabular}

The results for this closely related form are consistent with those obtained for Ulva, the action in the present case, however, being somewhat slower. The more common polysaccharides are acted upon while the disaccharides are not attacked.

\section{THE CARBOHYDRASES OF LAMINARIA AGARDHII}

The water extract from air-dried Laminaria tissue was extremely viscous and upon addition of alcohol, a very heavy precipitate was thrown down that contained a large amount of algal slime. When water was added to this precipitate in the usual ratio a very viscous diffusion was obtained. Ten cc. of the "diffusion-extract" were used with 50 cc. of the substrate and 2 per cent toluene added as an antiseptic. The flasks were kept at a temperature of $20-22^{\circ} \mathrm{C}$. for 100 days, 
portions being removed and sugar determinations made at the definite intervals noted in table $\mathrm{v}$.

The carbohydrases in this form appear to be limited to those acting on starch and dextrin, and with these the hydrolysis proceeds much more slowly than was true with either of the preceding "greens." The lower temperature at which the hydrolysis occurred does not explain completely the lessened action. Inhibiting substances or else an actually smaller concentration of the enzyme seem to be important factors.

TABLE V

THE ACTION OF A "DIFFUSION-EXTRACT" FROM AIR-DRIED LAMINARIA TISSUE UPON CERTAIN CARBOHYDRATES

\begin{tabular}{|c|c|c|c|c|}
\hline \multirow{2}{*}{ Substrate } & \multicolumn{4}{|c|}{$\begin{array}{c}\text { Sugar as glucose in } 5 \mathrm{cc} \text {. } \\
\text { mgms. }\end{array}$} \\
\hline & 15 days & 45 days & 75 days & 100 days \\
\hline 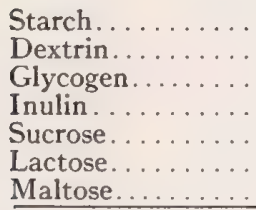 & $\begin{array}{c}\text { Trace } \\
\text { Trace } \\
\text { Trace } \\
\ldots . \\
\ldots\end{array}$ & $\begin{array}{l}3.25 \\
4.1 \\
\text { Trace } \\
\cdots \\
\cdots \\
\cdots \\
\cdots\end{array}$ & $\begin{array}{l}4.7 \\
6.85 \\
\text { Trace } \\
\text { Trace } \\
\text { Trace } \\
\text { Trace }\end{array}$ & $\begin{array}{l}6.5 \\
8.3 \\
\text { Trace } \\
\text { Trace } \\
\text { Trace } \\
\text { Trace }\end{array}$ \\
\hline
\end{tabular}

Another series (table vI) of flasks was set up with the same form, using a "diffusion-extract" from the fresh tissue. Ten cc. of this diffusion represented 6 grams of the Laminaria pulp. In addition to the usual substrates, .5 per cent laminarin was used. Toluene was added and the flasks maintained for 60 days at room temperature $\left(22-23^{\circ} \mathrm{C}\right.$.).

TABLE VI

THE ACTION OF A "DIFFUSION-EXTRACT" FROM FRESH LAMINARIA TISSUE UPON CERTAIN CARBOHYDRATES

\begin{tabular}{|c|c|c|c|c|c|}
\hline \multirow{2}{*}{$\begin{array}{l}\text { Substrate } \\
100 \mathrm{cc} .\end{array}$} & \multicolumn{5}{|c|}{$\begin{array}{c}\text { Sugar as glucose in } 5 \mathrm{cc} \text {. } \\
\text { mgms. }\end{array}$} \\
\hline & 7 days & 15 days & 30 days & 45 days & 60 days \\
\hline 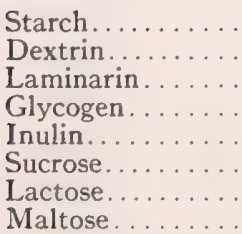 & $\begin{array}{l}\text { Trace } \\
\text { Trace } \\
\text { Trace } \\
\ldots \ldots \\
\ldots \ldots \\
\ldots \ldots\end{array}$ & $\begin{array}{c}\text { Trace } \\
\text { Trace } \\
2.4 \\
\text { Trace } \\
\ldots \ldots \\
\ldots \ldots\end{array}$ & $\begin{array}{c}2.7 \\
3.6 \\
3.9 \\
\text { Trace } \\
\ldots \ldots . \\
\text { Trace } \\
\text { Trace }\end{array}$ & $\begin{array}{l}4.2 \\
5.15 \\
5.4 \\
\text { Trace } \\
\text { Trace } \\
\text { Trace } \\
\text { Trace }\end{array}$ & $\begin{array}{l}5.35 \\
7.40 \\
5.65 \\
\text { Trace } \\
\text { Trace } \\
\text { Trace } \\
\text { Trace }\end{array}$ \\
\hline
\end{tabular}


The diastases of fresh Laminaria seem slightly more active than those isolated from the dried tissue; however, no other carbohydrases were evident than those shown in the previous table.

THE CARBOHYDRASES OF ASCOPHYLLUM NODOSUM AND MESOGLOEA DIVARICATA

The Mesogloea material was dehydrated as soon as brought into the laboratory, the preliminary fresh-water washing being omitted because of the rapid gelatinization of the tissue. The crushed dried tissue, extracted in the usual way, gave a very heavy, stringy precipitate with alcohol, consisting, as did that from Laminaria, mostly of slime. This, when diffused in the usual volume of water, gave a very viscous mixture. Crushed fresh Ascophyllum was extracted directly. The viscosity of the extract was high, but the alcohol precipitate from it came down in a flocculent mass that gave only a slightly viscous diffusion with water.

Experiments were set up with the various carbohydrates heretofore employed, including laminarin, and in the different series, amounts of the "diffusion-extract" were used varying from 5-15 cc. As was true with the Fucus reported in the previous study, in no case were there evidences of hydrolysis even after 60 days at room temperature.

\section{THE CARBOHYDRASES OF RHODYMENIA PALMATA}

The air-dried Rhodymenia tissue proved to give rise to one of the most viscous extracts encountered in the algae, 20 volumes of water being necessary to make handling possible. With alcohol, a very rubbery, white precipitate came down that was made up of a large proportion of algal slime. This diffused very slowly, giving an extremely viscous mixture. Ten cc. of the "diffusion-extract" were used with the substrate to determine action, and toluene was added. The flasks were kept at a temperature of $21-22^{\circ} \mathrm{C}$. for 100 days, sugar determinations being made from time to time, the results of which are given in table vII.

The results here are quite comparable to those obtained with Ulva and Enteromorpha, the same carbohydrates being 
acted upon, although perhaps a little more slowly. This action is definitely progressive with starch, dextrin, and laminarin, but with glycogen it takes a sudden jump during the 15-45day period, then remains practically stationary for the rest of the time the series is being maintained. As was true of the results shown in the previous tables, this carbohydrate was less favorable as a substrate than any of the other polysaccharides employed.

TABLE VII

THE ACTION OF A "DIFFUSION-EXTRACT" FROM AIR-DRIED RHODYMENIA TISSUE UPON VARIOUS CARBOHYDRATES

\begin{tabular}{|c|c|c|c|c|}
\hline \multirow{2}{*}{ Substrate } & \multicolumn{4}{|c|}{$\begin{array}{c}\text { Sugar as glucose in } 5 \mathrm{cc} \text {. } \\
\text { mgms. }\end{array}$} \\
\hline & 15 days & 45 days & 75 days & 100 days \\
\hline 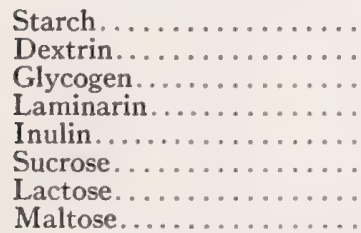 & $\begin{array}{l}9.2 \\
8.25 \\
\text { Trace } \\
4.7 \\
\cdots \\
\cdots \\
\cdots\end{array}$ & $\begin{array}{r}12.2 \\
9.7 \\
6.1 \\
7.3 \\
\text { Trace } \\
\cdots\end{array}$ & $\begin{array}{c}14.8 \\
10.3 \\
6.4 \\
9.6 \\
\text { Trace } \\
\text { Trace } \\
\text { Trace }\end{array}$ & $\begin{array}{l}18.2 \\
11.1 \\
6.7 \\
10.5 \\
\text { Trace } \\
\text { Trace } \\
\text { Trace } \\
\text { Trace }\end{array}$ \\
\hline
\end{tabular}

THE CARBOHYDRASES OF AGARDHIELLA TENERA

The very succulent nature of the freshly collected material compelled its partial dehydration immediately. Two 15minute treatments with 95 per cent alcohol were used, then the tissue spread out on paper toweling to dry at room temperature. After drying, it was very easily powdered without the aid of quartz sand. The alcohol precipitate from a water extract of this powder was quite fine and flocculent, differing much from that of Rhodymenia, both in amount and in nature.

\section{TABLE VIII}

THE ACTION OF A "DIFFUSION-EXTRACT" FROM DEHYDRATED AGARDHIELLA TISSUE UPON CERTAIN CARBOHYDRATES

\begin{tabular}{|c|c|c|c|c|}
\hline \multirow[t]{2}{*}{ Substrate } & \multicolumn{4}{|c|}{$\begin{array}{c}\text { Sugar as glucose in } 5 \text { cc. } \\
\text { mgms. }\end{array}$} \\
\hline & 15 days & 45 days & 75 days & 100 days \\
\hline 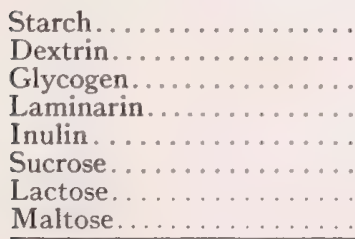 & $\begin{array}{l}6.35 \\
7.00 \\
2.35 \\
5.8 \\
\text { Trace } \\
\cdots \\
\cdots\end{array}$ & $\begin{array}{c}9.4 \\
10.5 \\
6.15 \\
8.3 \\
\text { Trace } \\
\text { Trace } \\
\cdots \cdots \\
\cdots\end{array}$ & $\begin{array}{l}14.5 \\
15.95 \\
6.65 \\
11.6 \\
\text { Trace } \\
\text { Trace } \\
\text { Trace }\end{array}$ & $\begin{array}{l}20.9 \\
19.7 \\
6.85 \\
13.2 \\
\text { Trace } \\
\text { Trace } \\
\text { Trace } \\
\text { Trace }\end{array}$ \\
\hline
\end{tabular}


It diffused readily in water with no resulting viscosity. Ten cc. of the "diffusion-extract" were used for enzyme action, toluene added, and the flasks kept at a temperature of $21-23^{\circ} \mathrm{C}$. for 100 days. The data here obtained are given in table viIr.

Dextrin here more nearly approaches starch as a favorable substrate, differing from the action evidenced by the other algae with the exception of Laminaria, where all action was slow. There is also a slightly increased action over that evidenced by Rhodymenia, for all the carbohydrates hydrolysed.

\section{THE CARBOHYDRASES OF CERAMIUM RUBRUM}

As was the case with Rhodymenia, it was necessary here to use 20 volumes of the water-extracting medium, not, however, because of the great viscosity, but on account of the great adsorption of water by the tissue particles. The alcohol precipitate was copious and finely flocculent. It diffused in water rather slowly, giving a mixture that was only slightly viscous. Ten ce. of the "diffusion-extract" were used for action, the usual percentage of toluene added, and the flasks maintained at a temperature of $21-23^{\circ} \mathrm{C}$. for 100 days. The data are given in table IX.

TABLE IX

THE ACTION OF A "DIFFUSION-EXTRACT" FROM FRESH CERAMIUM TISSUE UPON CERTAIN CARBOHYDRATES

\begin{tabular}{|c|c|c|c|c|}
\hline \multirow{2}{*}{ Substrate } & \multicolumn{4}{|c|}{$\begin{array}{c}\text { Sugar as glucose in } 5 \mathrm{cc} \text {. } \\
\text { mgms. }\end{array}$} \\
\hline & 15 days & 45 days & 75 days & 100 days \\
\hline 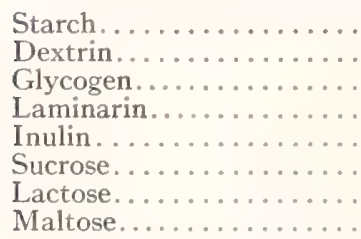 & $\begin{array}{l}6.85 \\
11.5 \\
\text { Trace } \\
7.2 \\
\cdots \\
\cdots \\
\cdots\end{array}$ & $\begin{array}{r}8.1 \\
15.0 \\
6.2 \\
9.4 \\
\text { Trace } \\
\text { Trace }\end{array}$ & $\begin{array}{l}11.75 \\
17.5 \\
7.3 \\
12.1 \\
\text { Trace } \\
\text { Trace } \\
\text { Trace }\end{array}$ & $\begin{array}{l}16.9 \\
19.6 \\
8.85 \\
12.2 \\
\text { Trace } \\
\text { Trace } \\
\text { Trace } \\
\text { Trace }\end{array}$ \\
\hline
\end{tabular}

Dextrin proved the most favorable substrate for the carbohydrate enzymes of this alga, the hydrolysis being about the same as that evidenced by Agardhiella. With the exception of glycogen, the other carbohydrates showed a decreased hydrolysis when compared with this latter form, and when 
compared with Ulva the difference is quite marked. As in the other algae, Ceramium showed no ability to hydrolyse the disaccharides used.

A COMPARISON OF THE DIASTATIC ACTIVITY OF ULVA LACTUCA WITH THAT OF LEAF TISSUE FROM SOLANUM TUBEROSUM

One of the very evident facts brought out by the data in the preceding tables was the relative slowness with which hydrolysis was carried on. This point made it seem worth while to compare, in a general way, the activity of such a form as Ulva with the starch-forming leaf tissue of a higher plant, one from which diastase could be isolated rather easily. The potato (Solanum tuberosum) was chosen.

The Ulva tissue was from an air-dried lot that had been tried out earlier and had been found quite active. Fresh potato tops were brought into the laboratory, and both these and the Ulva given the "dauerhefe" treatment. After dehydrating and drying at room temperature, both lots were ground in a mill, then reduced to a fine powder in a mortar. Exactly 18.5 grams of each were extracted with 250 cc. of water for 12 hours at room temperature with toluene added as an antiseptic, and then the protein-enzyme complex precipitated with 2.5 volumes of 95 per cent alcohol. The Ulva precipitate was the characteristic heavy white mass to which attention has been called before, while that of the potato was finely divided and dark.

The entire amount of each precipitate was diffused in $60 \mathrm{cc}$. of water. The Ulva precipitate gave a rather viscous diffusion, due to the adsorption of water by the protein particles; that from the potato did not all go into solution, making it necessary to shake the flask so that a true sample might be obtained. Five ce. of the "diffusion-extract" represented 1.84 grams of the original dehydrated tissue, and this volume was used with 50 cc. of a starch and dextrin substrate. Toluene was added as an antiseptic, and the flasks kept at a temperature of $31^{\circ} \mathrm{C}$. for 42 days. Portions of the substrate were removed from time to time and sugar determinations made, the results of which are shown in table $\mathrm{x}$. 
The action of the potato extract upon starch was about two and one-half times that of Ulva, and its action on dextrin about twice in all of the determinations made. For some unknown reason the hydrolysis of dextrin by the diastase from Ulva ceased after the twenty-eighth day.

TABLE X

A COMPARISON OF THE DIASTATIC ACTIVITY OF ULVA WITH THAT OF POTATO LEAF TISSUE

\begin{tabular}{|c|c|c|c|c|c|c|c|c|c|c|}
\hline \multirow{3}{*}{$\begin{array}{l}\text { Substrate } \\
50 \mathrm{cc} \text {. }\end{array}$} & \multicolumn{10}{|c|}{$\begin{array}{c}\text { Sugar as glucose in } 5 \mathrm{cc} \text {. } \\
\text { mgms. }\end{array}$} \\
\hline & \multicolumn{2}{|c|}{14 days } & \multicolumn{2}{|c|}{21 days } & \multicolumn{2}{|c|}{28 days } & \multicolumn{2}{|c|}{35 days } & \multicolumn{2}{|c|}{42 days } \\
\hline & Ulva & Potato & Ulva & Potato & Ulva & Potato & Ulva & Potato & Ulva & Potato \\
\hline 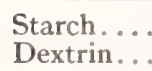 & $\begin{array}{r}8.7 \\
10.5\end{array}$ & $\begin{array}{l}18.1 \\
17.3\end{array}$ & $\begin{array}{r}9.6 \\
11.5\end{array}$ & $\begin{array}{l}26.3 \\
25.1\end{array}$ & $\begin{array}{l}11.8 \\
17.8\end{array}$ & $\begin{array}{l}28 \\
27\end{array}$ & $\begin{array}{l}12.9 \\
17.9\end{array}$ & $\begin{array}{l}33.5 \\
30.3\end{array}$ & $\begin{array}{l}13.8 \\
17.9\end{array}$ & $\begin{array}{l}35 \\
31\end{array}$ \\
\hline
\end{tabular}

ACTION OF VARIOUS ALGAL EXTRACTS UPON THE CARBOHYDRATE CONSTITUENTS OF AGAR-AGAR, AND OF VARIOUS GUMS, AS WELL AS EXPERIMENTS UPON THE AUTOLYSIS OF ALGAL SLIME

Because of the large amounts of carbohydrate-containing slime formed by many algae, and because of the rôle this might play as a reserve product, it was deemed advisable to try out the various algae for enzymes capable of hydrolysing such complex carbohydrates to assimilable sugars. It was assumed on the basis of the work done by König and Bettels ('05) and others, that such hydrolytic products would be reducing sugars, in all probability galactoses and pentoses.

A series was set up with each of the several algae, using 50 cc. of .25 per cent agar as a substrate and varying amounts of a "diffusion-extract" from fresh tissue. The agar substrate was slightly viscous in the cold, but when kept at a temperature of $40^{\circ} \mathrm{C}$., the optimum temperature for diastase, this was not noticeable. Toluene was used as an antiseptic. The flasks were shaken at regular intervals during a 30-day period and at the end of that time aliquot portions were removed and tested for reducing sugars. There was no reduction in any case.

As a parallel series, thin strips of agar were placed in testtubes and 20 ce. of "diffusion-extract" added. Toluene was used as an antiseptic and the tubes kept at a temperature of $40^{\circ} \mathrm{C}$. for two months. At the end of that time no hydrolytic 
action was observable, either by reduction of Fehling's or by microscopical examination.

In the experiments on the hydrolysis of various poly- and disaccharides, checks were set up in which the usual amount of "diffusion-extract" was placed in distilled water. This was to determine the reduction of copper, if any, due to the "diffusion-extract" itself. In no case was there more than a very slight trace that might have been due to other causes than enzymic. However, it was thought that a self-digestion series would more definitely determine whether the hydrolysis of the carbohydrates of the slime could be brought about by specific algal enzymes. With this in mind, a series was arranged in which the flasks contained 50 cc. of a water extract from each of the forms investigated. Checks were set up in which the "diffusion-extract" was inactivated in the autoclave. Toluene was used as an antiseptic and the flasks maintained at a temperature of $22-23^{\circ} \mathrm{C}$. for two months. Aliquot portions removed from time to time failed to show the slightest trace of hydrolysis.

It will be remembered that Tihomirov ('10) had found osozone-forming sugars in the conceptacles of Ascophyllum and Fucus that he thought might be dextrose and d-galactose, possibly also fucose and arabinose. Thinking that these might possibly have arisen from their corresponding anhydrides contained in the conceptacle slime, a self-digestion series was set up with an extract from the abscised, crushed conceptacles of those two forms. The Fucus was in a fruiting state. The series were set up in duplicate, one kept at room temperature and the other at $32-33^{\circ} \mathrm{C}$. Fehling's test showed no hydrolysis after a month.

Pentosans alone were then used as substrates. Two series of flasks for each of the algae investigated were set up, each containing a .5 per cent solution of gum arabic. ${ }^{1}$ To one series was added $10 \mathrm{cc}$., to the other $20 \mathrm{cc}$. of "diffusionextract," and the flasks placed at room temperature with toluene as an antiseptic. No hydrolysis was apparent either

\footnotetext{
${ }^{1}$ The gum arabic was dissolved in water, then precipitated with several volumes of 95 per cent alcohol to get rid of reducing sugars.
} 
by the phloroglucin test or by sugar determinations, even after 60 days.

\section{THE ACTION OF ALGAL "DIFFUSION-EXTRACTS" UPON CELLULOSE AND HEMICELLULOSE}

Experiments were carried out to determine the presence or absence of cellulose hydrolysing enzymes in the algae, and to this end several methods were employed. First, strips of filter paper were placed in test-tubes and entirely covered with 20 cc. of "diffusion-extract." Checks were maintained with distilled water and also with the "diffusion-extract" alone. The series were set up in duplicate-one kept at room temperature and the other at $35^{\circ} \mathrm{C}$., both with toluene as an antiseptic. After definite intervals during a 60-day period, the contents of the tubes were tested for reduction. None was observable in any case, and microscopic examination of the filter paper failed to reveal any decomposition whatsoever.

A double series was then set up in a similar way, except that 2 grams of fresh, crushed algal tissue were added to the tubes instead of the "diffusion-extract," together with 20 ce. of distilled water. At the periods noted above, microscopic examination revealed no attack. It was thought an inherent difference between algal and filter paper cellulose might be responsible for this absence of action. Accordingly, cellulose was prepared from the tissue of Ascophyllum after the method described by Fowler ('11, p. 159) and used by Cooley ('14). Fifty grams of air-dried tissue were placed in a liter flask, 500 cc. of distilled water added, and the lot placed in the autoclave at 15 pounds for 15 minutes to destroy any cellulase that might be present, and also to extract as much as possible of the water-soluble substances. The water was filtered from the tissue, fresh water added, and the flask placed in an incubator at $35^{\circ} \mathrm{C}$. It was kept at this temperature with daily changes of water for 10 days, at which time the water-soluble constituents seemed to be almost entirely removed. The treatment from here on was the same as that described by Cooley. To the tissue was added a liter of potassium-chlorate-nitric-acid solution made up in the proportion of 30 grams of potassium chlorate to 520 cc. of nitric 
acid (sp. gr. 1.1). The flask was kept in the ice-box for two weeks, when the oxidizing mixture was changed and the new lot allowed to remain another fortnight. At the end of this time a yellowish white tissue was obtained, representing fairly pure algal cellulose. This was filtered off, washed well with distilled water, and dried in the oven at $75-80^{\circ} \mathrm{C}$. The final product weighed 19.7 grams.

This cellulose was used in a way similar to the filter paper in the first series. One gram was placed in each flask and well shaken up with 50 cc. of distilled water. A concentrated "diffusion-extract" was prepared from Ascophyllum, Laminaria, Ulva, and Chondrus, 10 cc. of which represented 5 grams of the original dried tissue. This volume was added to the flasks, and the series set away at $30^{\circ} \mathrm{C}$. with toluene as an antiseptic. At the end of two months no reduction of Fehling's was observable and under the microscope there seemed to be no decomposition of the cellulose particles.

Action on hemicelluloses.-Hemicellulose was used from two sources-from date seeds, and from the seeds of the wild persimmon, Diospyros virginiana. In both cases the experiments were essentially the same. The horny coats were broken and the embryos removed. Small pieces of the hemicellulose were then taken, placed in a flask with water, and heated in the autoclave at 15 pounds for 15 minutes to kill the cytase present. Upon removal from the autoclave the pieces were washed several times in distilled water, being left in the last wash water for several days with toluene as an antiseptic-this to get rid of any reducing sugars present. Two of these washed pieces were placed in test-tubes with 10 cc. of the concentrated "diffusion-extract" used in the experiments with cellulose. Another lot was covered with $10 \mathrm{cc}$. of distilled water and 2 grams of the dried algal powder added. In a third series shavings of the hemicelluloses were mounted in a Van Tieghem cell with a drop of enzyme solution. All the algae under investigation were tried out, but in no case was there the slightest trace of decomposition, either microscopically or by the reduction of copper. 
Results.-These negative results do not necessarily argue against the production of slime through the agency of enzymes. It is impossible to exactly reproduce the conditions of the cell in vitro, and enzymes which might act upon cellulose in the living tissue to produce slime might easily be inhibited from action on cellulose or hemicellulose under the conditions of the experiments. Grüss ('10) found that fresh cherry gum contained cytase, but that none was demonstrable in the older gum. He also found that malt diastase would not act upon such gum until the tannins had been removed. It is known that the algae do contain tannins or "tannoidal" bodies, the writer having demonstrated a "tannoid" content in Ascophyllum of 1.1 per cent of the dry weight. These, or other agents, could be involved in the partial or complete inhibition of cytolytic action. On the other hand, indirect evidence, at least, points to the presence of the galactan and pentosan groups as due to their being laid down as such, that is, they do not arise as the direct result of hydrolytic enzyme action, but probably represent the final step in the condensation of those particular hemicelluloses. Tschirsch ('89) and his students have shown that the algal slime exists as an intracellular substance, and they hold that in most instances, at least, it does not arise from the cellulose. This seems to be the logical view, and we in turn seem justified in looking upon the galactan and pentosan groups in the algae as normal products of the plant's metabolism, present at all stages in the plant's growth, and capable of giving rise to gelatinization at any time upon the adsorption of water. If one examines, for instance, such forms as Fucus, Mesogloea, and Chondrus, the slime is hardly detectable when the plants are growing under normal conditions, but when brought into the laboratory and placed in fresh water, a rapid adsorption begins at once. The dissolved salts in sea-water are undoubtedly the inhibiting factors in such adsorption under normal conditions.

That this inhibition is not bound up with the living cell may be shown by the simple experiment of killing two fronds of Chondrus, for example, and placing one in fresh, the other 
in salt water, with toluene to keep down bacterial action. Very slight, if indeed any, gelatinization is evident with the frond placed in salt water, while that in fresh water begins to gelatinize immediately. It is also a well-known fact that in histological or cytological work with these forms, the killing fluids must be made up in sea-water or water containing a high percentage of salts, else gelatinization interferes. These facts, together with the apparent absence of cellulase and cytase, tend to show that the galactan and pentosan groups are always present as final condensation forms of their particular "generic" carbohydrate line, and that sliming in the marine algae, at least, is the result of the adsorption of water by these already existing carbohydrate groups.

\section{DISCUSSION OF RESULTS OF CARBOHYDRASE EXPERIMENTS}

It is seen from the data presented in the foregoing tables that carbohydrases in the algae, at least those that can be isolated by standard methods, are very few. Furthermore, in all cases where such carbohydrase action is evident, it is limited to the polysaccharides-starch, dextrin, laminarin, and glycogen. In no case were the disaccharides hydrolysed. As groups, the "greens" are more active than the "reds," while of the "browns," Laminaria is the only form in which carbohydrate action is demonstrable. Moreover, the action here is extremely slow and is limited to starch, dextrin, and laminarin. Mesogloea and Ascophyllum are similar to Fucus in failing to show the presence of carbohydrases. Within the groups there is little difference in the rate of carbohydrase action. This is especially true in the "greens." Of the "reds," Agardhiella is a little more active than the other forms investigated, while Ceramium is slightly the slowest. Bartholemew ('14), in the work already referred to, also found that Ceramium was less active than the other "reds" with which he worked.

The various polysaccharides, with two exceptions, prove favorable as substrates for the various algae in the same order, viz., starch, dextrin, laminarin, and glycogen. The carbohydrases of Ceramium act more rapidly upon dextrin than upon starch and this is also true of Laminaria, although 
to a lesser extent. Glycogen, which is very generally hydrolysed by diastase, is here decidedly less readily attacked than the other polysaccharides. This would seem to indicate that we are dealing with a distinct enzyme, one that might be placed in the same category with dextrinases. These latter always occur with the diastases but are held by many workers to be distinct.

Some of the substrates tested for hydrolysis do not, as far as we know, occur in the plants investigated. This is true of sucrose, lactose, and inulin. However, although this might reconcile us to the failure to find their specific enzymes, it does not argue conclusively against such enzymes being formed. It is well known that tissues do form ferments that have no detectable substrates upon which to act-the rennen of the bird's stomach and the urease of the Soja bean being notable examples. Inulin, as pointed out previously, does occur in certain "greens," as in Acetabularia and members of the Dasycladaceae. Unfortunately, none of these forms were available for investigation.

The absence of lactase and sucrase is not so significant as is that of maltase. It is very generally considered that in the plant, as well as in the animal organism, poly- and disaccharides must be hydrolysed to simple sugars before assimilation can take place. It is hardly possible that the algae are an exception to this general rule and yet it is difficult to account for this important negative result. It is known that inhibiting agents do not affect all enzymes alike, and it may be here that if such agents are liberated on the death of the cell, the maltase might prove more sensitive to them than the other carbohydrate enzymes. According to the findings of Kylin ('13), both dextrose and fructose have been demonstrated in the tissues of Ascophyllum, Fucus, and Laminaria, but in extremely small quantities. These results would tend to convince one that an enzyme giving rise to them is probably present in the algal cell.

Such carbohydrates as galactans, pentosans, and mannans, are very frequently met with in the algae and are potentially capable of being split to assimilable sugars. That they are 
not so split, however, seems evident, at least not through the activity of demonstrable algal enzymes, and in the face of the negative evidence obtained, we would consider them as byproducts of metabolism rather than as playing the rôle of reserves. As such, they would not be so comparable to the reserve carbohydrates of the date as they would be perhaps to the mucilaginous constituents of various seeds, as those of flax, mistletoe, etc. These latter adsorb water readily with gelatinization, and as far as is known, never function as reserves but act in a purely mechanical way (Czapek, '13, p. 705).

\section{LIPASES IN THE ALGAE}

The almost universal presence of fats in the marine algae led to the question of their assimilation. Accordingly, experiments were set up to determine the lipolytic activity upon emulsions of neutral fats as well as upon certain esters of the lower fatty acids. For the neutral fats olive oil was chosen as a substrate, and two general methods were employed in forming the emulsion.

The first, an olive oil-casein emulsion was made up after a method described by Bloor ('14). Four grams of casein were placed in a warm mortar on a water bath and water added until the whole formed a paste of medium viscosity. A drop of phenylphthalein was added, then $\mathrm{N} / 1 \mathrm{NaOH}$ poured in and stirred with the casein until the latter had been dissolved, this point being indicated by a permanent pink tinge of the mixture. Eight cc. of olive oil were stirred into the hot solution and then ground with a pestle until all the oil globules had disappeared. At this point the mortar was removed from the bath and the emulsion cooled. During the cooling it was found necessary to stir the mixture occasionally. The thick, creamy mass resulting was diluted up to the required concentration by the careful addition of water. If this dilution is too great, the oil globules tend to rise to the surface.

The second method was also suggested by Doctor Bloor, but, as far as is known, has not been described. Eight cc. of olive oil were dissolved in the smallest amount of absolute alcohol necessary. This solution was run through a hot fun- 
nel to which a drawn-out piece of glass tubing had been attached, into about $100 \mathrm{cc}$. of cold distilled water, the water being stirred constantly while the olive oil was being run in. A milk-white emulsion made up of extremely small suspended globules of oil resulted. In an emulsion carefully made, most of these globules are small enough to show Brownian movement. The alcohol was driven off finally by heating and the emulsion made up to the desired concentration.

Both emulsions stand up well. In the latter, however, there is a tendency toward flocking out by some of the smaller particles upon the addition of any salt-containing substance, such as, for instance, algal powder; but, on the other hand, it has the advantage of being more easily checked up because of its simpler composition.

TABLE XI

LIPOLYTIC ACTION OF THE SEVERAL ALGAE UPON OLIVE OILCASEIN EMULSION

\begin{tabular}{|c|c|c|c|c|c|c|c|c|c|c|c|c|}
\hline \multirow[b]{3}{*}{ Alga } & \multicolumn{12}{|c|}{ Number cc. of $\mathrm{N} / 10 \mathrm{NaOH}$ to neutralize $10 \mathrm{cc}$. of substrate } \\
\hline & \multicolumn{4}{|c|}{4 days } & \multicolumn{4}{|c|}{10 days } & \multicolumn{4}{|c|}{15 days } \\
\hline & 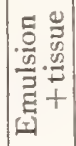 & $\frac{5}{0.0}$ & $\sum^{\frac{3}{3}}$ & 音 & 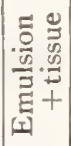 & $\frac{\tilde{E}}{\stackrel{0}{n}}$ & $\frac{0}{3}$ & $\frac{\lambda}{2}$ & 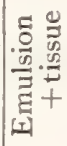 & 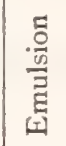 & 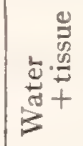 & 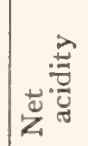 \\
\hline Ulva & & & & & 1.3 & .25 & .1 & .95 & & & & \\
\hline Enteramor & & & & & 1. 25 & .2 & 1 & .95 & & & & \\
\hline Mesogloea & .6 & .00 & .1 & .5 & 1.00 & 1 & .1 & .8 & 2.2 & .6 & .075 & 1.525 \\
\hline Ascophyllum & & & & & 1. 50 & .05 & 1.0 & .45 & & & & \\
\hline Laminaria. & & & & & .4 & .00 & .05 & .35 & .6 & .1 & .025 & .475 \\
\hline Chondrus & 1.2 & .00 & .05 & 1.15 & 1.85 & .00 & .05 & 1.8 & 2.3 & & .1 & 2.200 \\
\hline A gardhiella & $\ldots$ & $\ldots$ & & & .3 & .00 & .05 & .25 & & 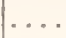 & $\ldots$ & . \\
\hline Ceramium & & & & & 1.6 & .00 & .1 & 1.5 & & & & \\
\hline Rhodymenia & .3 & .1 & .05 & .15 & .9 & .2 & 15 & .55 & & & & \\
\hline Champia. & 2 & .1 & .05 & .05 & .35 & .3 & .05 & .00 & & & & \\
\hline
\end{tabular}

In all the lipolytic experiments, algal powder or fresh algal tissue crushed with fine quartz sand, was used as a source of enzyme action. In some of the original series the olive oilcasein emulsion was employed, but on account of the danger arising from a possible hydrolysis of the casein with a resulting increase in acidity, the alcohol emulsion was used in the later work.

Lipolytic action of the several algae upon olive oil-casein emulsion.-In this experimental series (table xI) flasks were set up containing 50 cc. of olive oil-casein emulsion as a sub- 
strate, 5 grams of crushed algal tissue for enzyme action, and 10 cc. of 95 per cent alcohol as an antiseptic. Checks were employed wherein the flasks in one case contained the emulsion alone, and in another case, the same weight of algal pulp in distilled water. The flasks were maintained for 15 days except for the forms especially noted. At intervals 10 cc. portions were removed and titrated against $\mathrm{N} / 10 \mathrm{NaOH}$ with phenylphthalein as an indicator.

Lipolytic action on alcohol-water-olive oil emulsion.-Because of the possibility of the hydrolysis of the casein in the emulsion used in the preceding experiments, a series (table xII) employing the alcohol-water emulsion was set up as a check. This emulsion alone was practically neutral but a

TABLE XII

LIPOLYTIC ACTION OF THE SEVERAL ALGAE UPON ALCOHOL-WATER-OLIVE-OIL EMULSION

\begin{tabular}{|c|c|c|c|c|c|}
\hline \multirow{2}{*}{ Alga } & \multicolumn{5}{|c|}{$\begin{array}{l}\text { Number } \mathrm{cc} . \mathrm{N} / 10 \mathrm{NaOH} \text { to neutralize } 10 \mathrm{cc} \text {. } \\
\text { substrate after } 10 \text { days }\end{array}$} \\
\hline & $\begin{array}{c}\text { Emulsion } \\
+ \text { tissue }\end{array}$ & $\begin{array}{l}\text { Emulsion } \\
\text { alone }\end{array}$ & $\begin{array}{c}\text { Water }+ \\
\text { boiled tissue }\end{array}$ & $\begin{array}{c}\text { Water+ } \\
\text { tissue }\end{array}$ & $\begin{array}{l}\text { Net } \\
\text { acidity }\end{array}$ \\
\hline 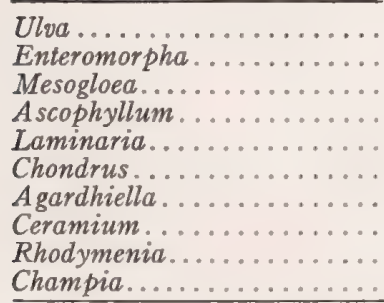 & $\begin{array}{l}.9 \\
.8 \\
.65 \\
.2 \\
1.15 \\
1.45 \\
.25 \\
.85 \\
.525 \\
.125 \\
\end{array}$ & $\begin{array}{l}.00 \\
.00 \\
.00 \\
.00 \\
.00 \\
.00 \\
.00 \\
.00 \\
.00 \\
.00\end{array}$ & $\begin{array}{l}.05 \\
.025 \\
.05 \\
.15 \\
.02 \\
.1 \\
.05 \\
.1 \\
.05 \\
.15\end{array}$ & $\begin{array}{l}.05 \\
.1 \\
.075 \\
.15 \\
.3 \\
.35 \\
.05 \\
.20 \\
.15 \\
.15 \\
\end{array}$ & $\begin{array}{l}.85 \\
.7 \\
.575 \\
.05 \\
.85 \\
1.10 \\
.20 \\
.65 \\
.375 \\
.00\end{array}$ \\
\hline
\end{tabular}

slight acidity was produced by the addition of the algal powder. A negligible amount of the oil globules ran together and collected at the surface of the liquid after some days, but the bulk of the emulsion stood up well. As in the preceding series, 5 grams of the fresh tissue were used as a source of lipolytic activity, and the alcohol in which the olive oil had been dissolved served as an antiseptic. Fifty cc. of the emulsion were used as a substrate, and the flasks maintained at a temperature of $22-23^{\circ} \mathrm{C}$. for 10 days.

Lipolytic action on triacetin.-The lipolytic activity of dry tissue powder of Ulva, Mesogloea, and Chondrus was tested, using a .5 per cent solution of triacetin as a substrate. Two 
grams of the tissue powder were used, otherwise the series (table xiII) was arranged exactly as the preceding and kept at room temperature for 25 days.

Action on other esters.-A series was set up with methyl acetate, ethyl acetate, and ethyl butyrate in .25 per cent solution, using 2 grams of algal powder with 50 ce. of the sub-

TABLE XIII

THE ACTION OF POWDERED TISSUE FROM CERTAIN ALGAE UPON TRIACETIN

\begin{tabular}{|c|c|c|c|c|c|c|c|c|}
\hline \multirow{3}{*}{ Alga } & \multicolumn{8}{|c|}{$\begin{array}{l}\text { Number cc. of } \mathrm{N} / 10 \mathrm{NaOH} \text { to neutralize } \\
10 \mathrm{cc} \text {. substrate after }\end{array}$} \\
\hline & \multicolumn{4}{|c|}{10 days } & \multicolumn{4}{|c|}{25 days } \\
\hline & $\begin{array}{c}\text { Tri- } \\
\text { acetin } \\
\text { + tissue }\end{array}$ & $\begin{array}{c}\text { Water }+ \\
\text { tissue }\end{array}$ & $\begin{array}{l}\text { Tri- } \\
\text { acetin } \\
\text { alone }\end{array}$ & $\begin{array}{c}\text { Net } \\
\text { acidity }\end{array}$ & $\begin{array}{c}\text { Tri- } \\
\text { acetin } t \\
\text { tissue }\end{array}$ & $\begin{array}{c}\text { Water }+ \\
\text { tissue }\end{array}$ & $\begin{array}{l}\text { Tri- } \\
\text { acetin } \\
\text { alone }\end{array}$ & $\begin{array}{l}\text { Net } \\
\text { acidity }\end{array}$ \\
\hline $\begin{array}{l}\text { Ulva.......... } \\
\text { Mesogloea..... } \\
\text { Chondrus..... }\end{array}$ & $\begin{array}{l}.3 \\
.25 \\
.55\end{array}$ & $\begin{array}{l}.025 \\
.05 \\
.35\end{array}$ & $\begin{array}{l}.1 \\
.1 \\
.1\end{array}$ & $\begin{array}{l}.175 \\
.1 \\
.1\end{array}$ & $\begin{array}{l}.5 \\
.4 \\
.8\end{array}$ & $\begin{array}{l}.15 \\
.2 \\
.4\end{array}$ & $\begin{array}{l}.15 \\
.15 \\
.15\end{array}$ & $\begin{array}{l}.2 \\
.05 \\
.25\end{array}$ \\
\hline
\end{tabular}

strate in 20 per cent alcohol. Titrations were made from time to time against $\mathrm{N} / 10 \mathrm{NaOH}$ with phenylphthalein as an indicator. Even after 60 days at room temperature no increase in acidity was observable over the checks.

General results for experiments with lipases.-The results serve to show that, although slight, there is distinct lipolytic activity in most of the forms investigated. The various groups of algae are not so distinct regarding this activity as was the case with the carbohydrases, nor does the activity of the individual alga in this case relate itself particularly to the activity shown by the form in its carbohydrase action. Agardhiella hydrolyses the polysaccharides more rapidly than any other alga, yet its lipolytic activity is very low. Likewise, Laminaria, so inactive in the previous group of enzymes, is among the most active on fats. Fucus, on the other hand, was found in previous work to have no action on either carbohydrates or fats.

The action is especially evidenced by use of the olive oilcasein emulsion. In general, the increases were less where the alcohol-water emulsion was used-a difference probably ex- 
plainable on the ground that the casein gave rise to a slight acidity.

Specificity of action might explain the failure to obtain action on most of the esters. Euler ('12) differentiates the lipases into true lipases and esterases, the former acting on neutral fats particularly, the latter on the methyl and ethyl esters of the lower fatty acids. Even in this latter restricted field, great specificity may be shown. Reed ('12) found that ethyl acetate was quite rapidly acted upon by an esterase isolated from Glomerella rufomaculans, while ethyl butyrate was only slightly hydrolysed.

\section{THE PROTEINASES}

The proteolytic activity of the various algae was tested on albumin, casein, legumin, peptone, gelatin, and in certain cases, on proteins isolated from the algal tissue-most of these under acid, alkaline, and neutral conditions. The first four were made up in 1 per cent concentrations. Albumin and peptone went into solution quite readily; legumin and casein, being insoluble in water, were either weighed out directly, or dissolved in $\mathrm{N} / 10 \mathrm{NaOH}$. The albumin and gelatin were also tested in the form of Mett's tubes, and the gelatin alone in test-tubes where it was held at a temperature high enough to keep it in a liquid state while in contact with the algal powder. In all cases, algal tissue was used directly, either fresh crushed, or dry powdered-usually 2 grams of the powder or 5 grams of the fresh tissue to each $50 \mathrm{cc}$. of substrate.

Determination of hydrolysis.-Proteolytic action was determined in several ways, each acting as a check on the others. The biuret test was used for the demonstration of tryptic action, the proteins being precipitated by $\left(\mathrm{NH}_{4}\right)_{2} \mathrm{SO}_{4}$ in saturated solution and the test applied in the usual way. The tryptophane test was employed for ereptic action and this also furnished a check on the action of trypsin. In this, 1 cc. of the protein solution was placed in a small evaporating dish, a drop of glacial acetic acid added, and then a few drops of strong chlorine water. The hydrolysis to the amino acid stage 
was also demonstrated in two other ways-by the formaldehyde-titration method of Sörenson ('08), and the determination of the amino-nitrogen by the micro-Kjeldahl method of Folin ('13). The Sörenson method consisted in adding 2 cc. of formalin, made alkaline to a faint pink tinge with $\mathrm{N} / 20$ $\mathrm{NaOH}$, to $10 \mathrm{cc}$. of the filtered protein solution, made alkaline to the same color. Upon mixing, the color disappeared and the acidity resulting was titrated against $\mathrm{N} / 50 \mathrm{NaOH}$, using phenylphthalein as an indicator.

In the determination of the amino-nitrogen by the "micro" method of Folin, the protein in a 5 cc. filtered portion of the solution was precipitated with 2 cc. of a 25 per cent solution of phosphotungstic acid in 5 per cent $\mathrm{H}_{2} \mathrm{SO}_{4}$. The precipitate was filtered off and a 2 cc. portion of the filtrate removed for the determination of the nitrogen. Duplicate determinations were made in all cases. These portions were placed in Jena test-tubes, $20 \times 200 \mathrm{~mm}$., 1 cc. concentrated $\mathrm{H}_{2} \mathrm{SO}_{4}$ added, then 1 gram of $\mathrm{K}_{2} \mathrm{SO}_{4}$, and a drop of 5 per cent $\mathrm{CuSO}_{4}$. The digestion was carried on over the flame from a micro burner, the fumes being carried away by the fume adsorbers described by Folin. Usually 20 minutes sufficed for the completion of the digestion, although in a few instances 25 minutes were required. After cooling slightly, 6 cc. of distilled water were carefully added. The tubes were then transferred to the distilling apparatus where concentrated $\mathrm{NaOH}$ was added to alkalinity, and the tube contents distilled over for three minutes, the $\mathrm{NH}_{3}$ being collected in a known volume of $\mathrm{N} / 10$ $\mathrm{HCl}$. The acid in the collection flask was titrated against N/10 $\mathrm{NaOH}$ with alizarin red (alizarin sulfonsäure Natrium, Merck), and the amount of nitrogen represented by the acid neutralized, determined.

In the method originally described by Folin, the $\mathrm{NH}_{3}$ was not distilled but was forced over from an alkaline solution by a strong air current. However, students in his laboratory have made use of a micro distilling apparatus, and the suggestion for the ones employed here owes its origin to one of Folin's assistants. Distillation has the advantage of quickness, and from the writer's experience, of accuracy as well, 
at least where suction instead of compressed air is employed in the air method. The results with the air current were very often below the theoretical. The distilling tubes used were made in the laboratory from glass tubing, the outer jacket measuring $40 \times 2 \mathrm{~cm}$, and the inner being $5 \mathrm{~mm}$. in diameter. The lower end of this latter, where it dipped into the collection acid, was fitted with a larger tube $14 \mathrm{~mm}$. in diameterthis to prevent a back flow of the acid; to the upper end of this inner tube was attached a safety bulb made from a $10 \mathrm{cc}$. pipette, and this in turn fitted into the Jena tube containing the distilling mixture, by means of a two-hole rubber stopper. Through the second hole in this stopper was a small piece of glass tubing closed at the upper end with a bit of rubber tubing and a pinch clamp; it was through this that the alkali was added after the apparatus was connected up for distillation.

Considerable trouble was experienced at first with bumping, especially after the digestion mixture had become concentrated. Neither bits of glass nor pebbles would overcome it. Finally the expedient was adopted of using short pieces of glass tubing sealed at one end and this end placed uppermost. These were of such a diameter that after digestion, the digestion mixture drawn up into them by the cooling of the contained air, would easily drain out when the boiling tube was forced up on the side of the test-tube by a quick downward motion.

The action of Enteromorpha, Mesogloea, and Chondrus powder upon various proteins.-Fifty cc. lots of casein, legumin, albumin, and peptone were used as substrates in this series-all in 1 per cent concentrations. The albumin and peptone were dissolved directly in distilled water, the legumin and casein in $\mathrm{N} / 10 \mathrm{NaOH}$. Two grams of air-dried tissue powder were used for proteolytic action, with the exception, however, of Mesogloea, which, as before stated, was partially dehydrated before being air-dried. The various substrates were made neutral by the addition of $\mathrm{N} / 10$ alkali and then acid or alkaline by further addition of 2.5 ce. of N/10 HCl or $\mathrm{NaOH}$. In the formaldehyde titrations $10 \mathrm{cc}$. of the sub- 


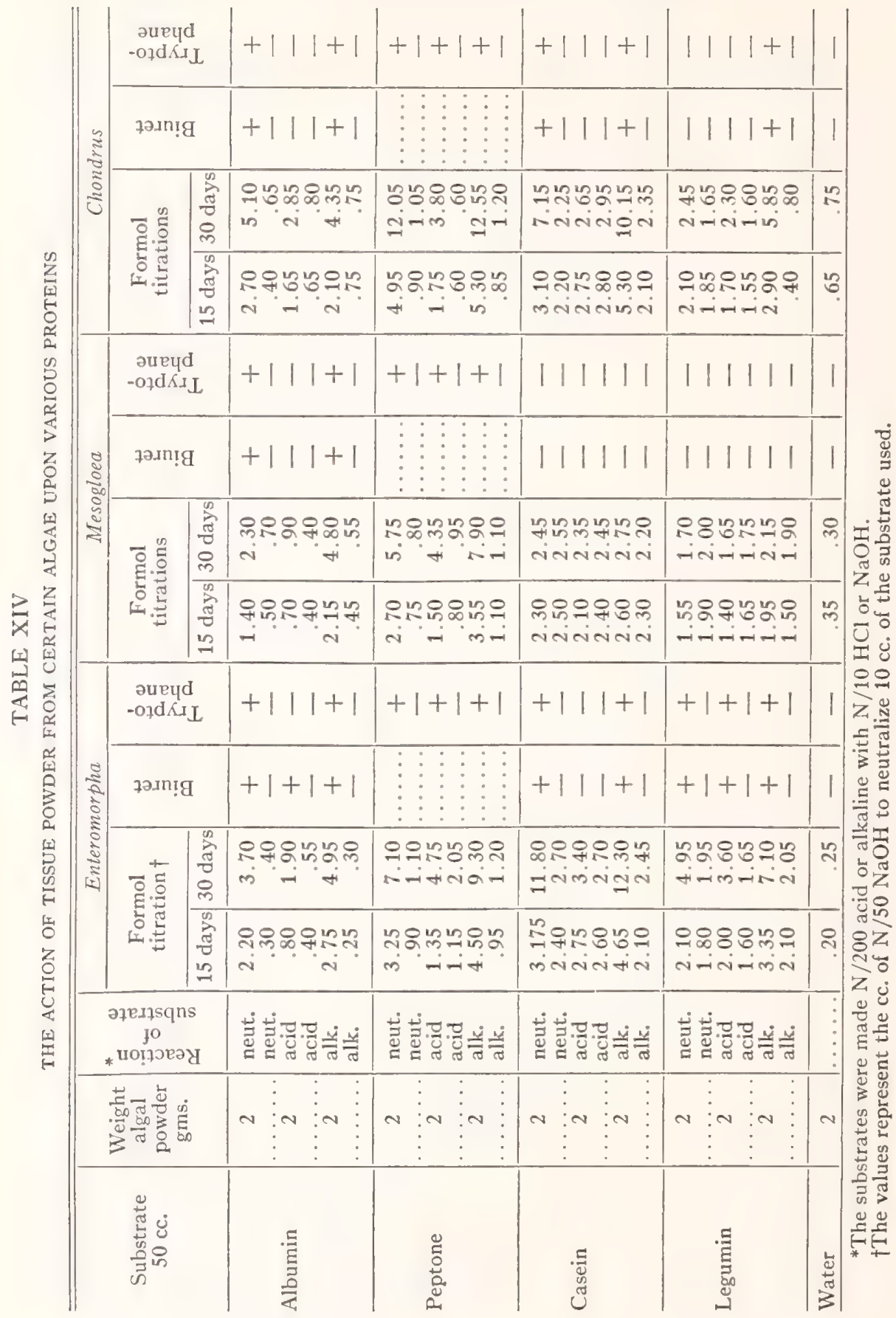


strate were titrated against $\mathrm{N} / 50 \mathrm{NaOH}$. One per cent chloroform-thymol was used as an antiseptic, and the flasks were kept at a temperature of $22-23^{\circ} \mathrm{C}$. for 30 days.

The forms used in table XIV show a general ability to hydrolyse proteins. All four proteins employed were acted upon by one alga or another, but peptone and casein in neutral and alkaline solution were the most readily attacked. Enteromorpha split albumin and legumin but poorly; Chondrus acted upon legumin only in alkaline solution, and then slightly; Mesogloea failed to hydrolyse casein and legumin, and its action on albumin and peptone was very slow.

The action of Ulva, Laminaria, and Agardhiella powder on peptone and casein in alkaline and neutral solution.-Indications in the preceding experiment seemed to point to the fact that peptone and casein were more easily acted upon than the other proteins-and these more especially in neutral and alkaline solution. Accordingly, a series was set up with these two substrates, similar in all respects to the preceding one, except that the acid substrate was omitted and that Ulva, Laminaria, and Agardhiella were used for proteolytic action. Five grams of air-dried tissue were employed with $100 \mathrm{cc}$. of substrate. One per cent chloroform-thymol served as an antiseptic, and the flasks were kept at $35^{\circ} \mathrm{C}$. for 30 days. Formaldehyde titrations were made after 15 and 30 days and tryptophane tests and amino-nitrogen determinations after 30 days. In the titrations 10 cc. of substrate were titrated against N/50 $\mathrm{NaOH}$, and the amino-nitrogen represents that in $2 \mathrm{cc}$. of the filtrate from phosphotungstic precipitated protein.

The data in table $\mathrm{xv}$ tend to substantiate that of table xIV concerning the hydrolysis of peptone and casein. The higher temperature at which the flasks were maintained undoubtedly had something to do with the larger amounts of amino acids split off from these two proteins than was the case in the preceding series, yet if we can judge by the action on carbohydrates and fats, we are dealing here with the more active members, enzymatically, of their respective groups.

On the whole, peptone and casein seem to be the most favorable substrates of those used for proteolytic activity, and 


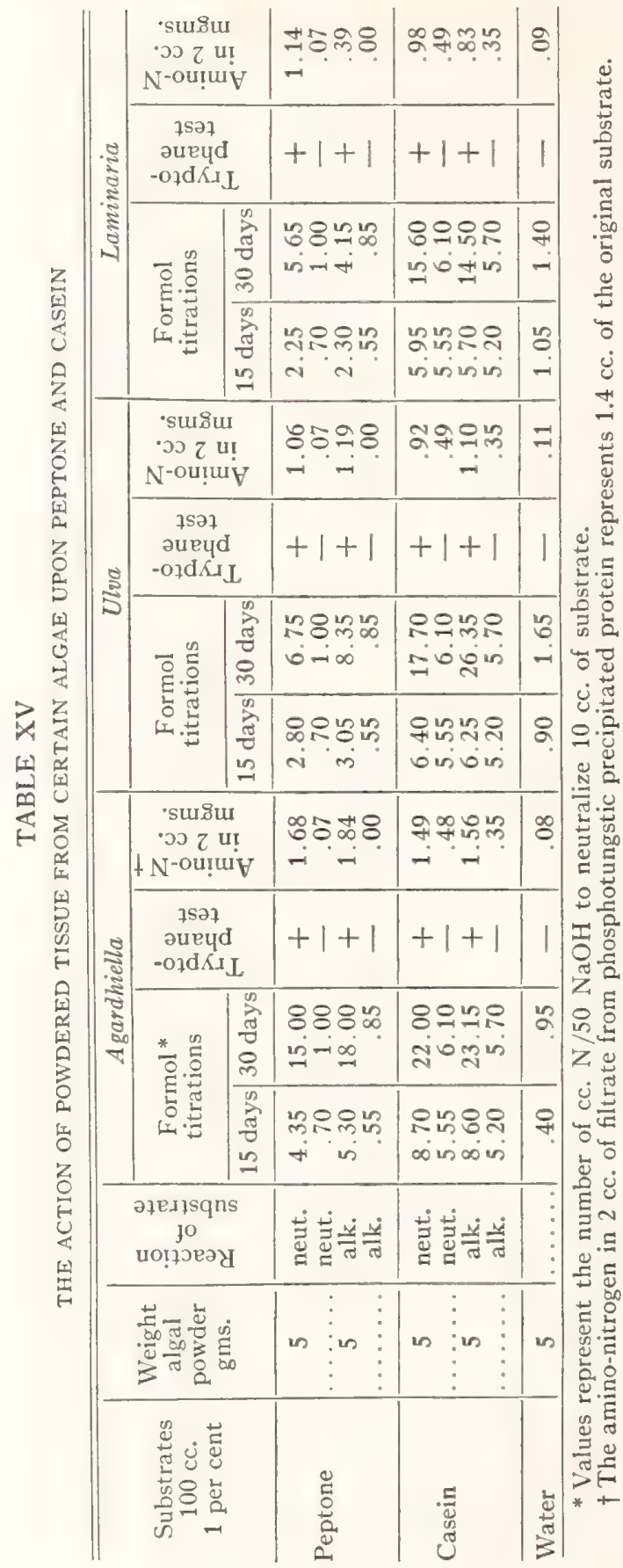


these in neutral and slightly alkaline solution. This was shown in the formol titrations ${ }^{1}$ and in the determination of the nitrogen in the amino acids split off. Albumin was slowly acted upon by Enteromorpha, Mesogloea, and Chondrus. The first and last also hydrolysed the vegetable protein, legumin, to a slight extent-an action that was not shared by Mesogloea.

The action of algal powder on the proteolysis of gelatin and albumin in Mett's tubes.-Two lots of Mett's tubes were made up, one containing coagulated egg-white, and the other, 15 per cent gelatin. In each of a series of flasks containing 50 ec. of distilled water, $\mathrm{N} / 200 \mathrm{NaOH}$ and $\mathrm{N} / 200 \mathrm{HCl}$ respectively, were placed one tube each of egg-white and gelatin. Two grams of the powdered tissue from each of the several forms under investigation were added for enzyme action and the usual percentage of toluene used as an antiseptic. The several series were kept for two months at room temperature. At the end of that time the albumin tubes in the alkaline solution containing the algal powder of Ulva, Enteromorpha, Chondrus, and Agardhiella showed a slight digestion. The checks in the alkaline solution alone showed swelling. However, although this was indicative of action, it was not definite, since the great length of time the protein was in contact with the complex constituents of the tissue may have been a factor in either causing a slight hydrolysis or a contraction of the albumin. On the other hand, Laminaria, Ascophyllum, Mesogloea, and Ceramium caused no such action. The gelatin tubes showed no evidences of action even after 60 days.

The effect of proteinases on the hardening of gelatin.-Dox ('10) describes a method for testing the hydrolysis of gelatin which consists in keeping the protein in a liquid state during contact with the material being tested for proteolytic activity, then at the end of a stated period noting whether the gelatin congeals when placed in cold water. This method was used in the following way: Five cc. of 20 per cent gelatin were placed in each of a series of test-tubes, and $5 \mathrm{cc}$. of the standard

1 The formaldehyde titrations, as used here, were satisfactory only in a general way, i. e., to show relative rather than exact differences in the amounts of amino acids split off. The differences brought out by the amino-nitrogen determinations are much more exact. 
"diffusion-extract," described under "carbohydrases," used for action. The contents of the tubes were made neutral, and acid and alkaline to $\mathrm{N} / 200$, as was done in the other proteolytic experiments. Five drops of chloroform-thymol were added as an antiseptic. Checks were set up containing the gelatin together with 5 cc. of boiled "diffusion-extract." The tubes were placed in an incubator at $35^{\circ} \mathrm{C}$. for a week, at which time they were removed and cooled in running water. All tubes hardened in a short time, showing that no hydrolysis had taken place.

General results for experiments on proteolysis.-The proteolytic activity, although slow, as was the case with the other enzymes investigated, is definite enough to warrant the statement that proteinases and peptases are very generally present in the algae. When present, such enzymes act best under neutral and alkaline conditions. This last finding is interesting in the light of the existing differences of opinion regarding the relative value of acid and alkaline substrates for vegetable proteinases. It will be recalled that Vines ('97) found that acidity favored the proteinase contained in the leaf pitchers of Nepenthes, and in a later paper, he states that peptase (hydrolysing albumoses and peptones to amino acids) always act best under faintly acid conditions. Emmerling ('02), on the other hand, demonstrated that the papain of Carica papaya acted more rapidly when the substrate was alkaline. Euler ('12) states in a general way that peptases require a neutral or faintly alkaline substrate, and proteinases (tryptases) an acid one.

Of the proteins employed, solutions of casein and peptone prove the most favorable substrates. Albumin in solution is acted upon slowly, but when employed in the form of Mett's tubes, doubt exists regarding its digestion. Legumin appears to be slowly hydrolysed by Enteromorpha and Chondrus, but not by Mesogloea. Gelatin, either in the liquid state or in the form of Mett's tubes, is not attacked. As groups, the "reds" appear more active in proteolysis than do the " greens," while, as was true for carbohydrases, the "browns" show the least activity. 


\section{THE AMIDASES}

The tissues from the several algae were tested for their ability to split $\mathrm{NH}_{3}$ from such amino and amido compounds as urea, acetamid, asparagin, and methyl amine. These compounds were used in 1 per cent concentrations. Series were set up in which $50 \mathrm{cc}$. of the substrate to be tested were placed in flasks together with 2 grams of the powdered tissue and chloroform-thymol as an antiseptic. Checks were used with the nitrogen compounds alone and with the algal tissue in distilled water. The flasks of duplicate series were kept at room temperature and at $35^{\circ} \mathrm{C}$. respectively, for 30 days, at the end of which time Folin's method was employed for the determination of any $\mathrm{NH}_{3}$ that might have been split off. In the collection of the $\mathrm{NH}_{3}$, Friedrich's improved gas washing bottles containing 250 cc. of $\mathrm{N} / 50 \mathrm{HCl}$ were used. Air was bubbled through by means of a suction pump for two hours, then 25 cc. portions of the collection acid were removed and titrated against $\mathrm{N} / 50 \mathrm{NaOH}$, with alizarin red as an indicator. In no case was there any action over that evidenced by the checks.

These results are extremely interesting, in the case of Ulva especially. This form, as has been shown, thrives in waters where the organic nitrogen content is high. The question would at once arise whether this increased growth were due to the ability of the Ulva to break down the protein molecule and thus obtain an increased supply of nitrogen as $\mathrm{NH}_{3}$, or whether it were due to the activities of the denitrifying bacteria rendering available a larger assimilable supply. That such bacteria are relatively abundant in sewage-contaminated water has been shown in the review of literature. We can conceive of another factor entering in-that of selective formation of enzymes. It might well be that with plenty of the amino-nitrogen available through the activity of bacteria, no amidases would be formed. The possibility of shedding some light on this point led to the experiments following.

Experiments on amidase formation by Chlamydomonas.Chlamydomonas was grown in pure culture upon two different media; one (with one or two modifications, that used by 
Schramm ('14)), containing $\left(\mathrm{NH}_{4}\right)_{2} \mathrm{SO}_{4}$ as a source of nitrogen, the other with nitrogen supplied as peptone and asparagin. These media complete were as follows:

A.

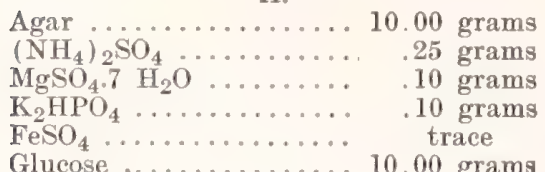

Distilled $\mathrm{H}_{2} \mathrm{O} \ldots \ldots .500 .00$ cc.
B.

Agar .............. 10.00 grams

Peptone .......... 4. 00 grams

Asparagin ........... 1.00 grams

$\mathrm{MgSO}_{4} .7 \mathrm{H}_{2} \mathrm{O} \ldots . . . . .10$ grams

$\mathrm{K}_{2} \mathrm{HPO}_{4} \ldots \ldots \ldots . . . . .10$ grams

$\mathrm{FeSO}_{4} \ldots \ldots \ldots$ trace

Glucose .............. 10.00 grams Distilled $\mathrm{H}_{2} \mathrm{O} \ldots . . .500 .00$ c..

These media, designated "A" and "B," were placed in 125 cc. Erlenmeyers, about 25 cc. to each flask, and the flasks placed horizontally until the agar hardened. A relatively large surface was obtained in this way and the harvesting of the alga later was facilitated. In inoculation, the alga was smeared over the surface of the agar to give an even growth. After a growth of thirty days, it was harvested by scraping from the agar surface with a stiff, platinum needle. The cells were then dehydrated with alcohol, acetone and ether, dried, and ground with an equal weight of fine quartz sand. Flasks were set up in duplicate in Wollf wash bottles, using 1 per cent asparagin as a substrate, with an amount representing .35 grams of sand-free algal powder. Checks were run on both the asparagin and the algal powder alone. One-half the series was taken down at the end of 7 days, the other half at the end of 15 days, and the $\mathrm{NH}_{3}$ split off determined by the Folin method previously employed. The flasks were kept at a temperature of $35^{\circ} \mathrm{C}$. The results are given in table xvI.

TABLE XVI

THE ACTION OF DEHYDRATED CHLAMYDOMONAS CELLS UPON ASPARAGIN

\begin{tabular}{|c|c|c|c|c|c|}
\hline \multirow{2}{*}{$\begin{array}{l}\text { Substrate } \\
50 \mathrm{cc} \text {. } \\
1 \text { per cent }\end{array}$} & \multirow{2}{*}{$\begin{array}{l}\text { Weight } \\
\text { algal } \\
\text { powder }\end{array}$} & \multicolumn{4}{|c|}{$\begin{array}{c}\text { Nitrogen as } \mathrm{NH}_{3} \text { in } 50 \text { cc. substrate } \\
\text { mgms. }\end{array}$} \\
\hline & & 7 days & Net N & 15 days & Net $\mathbf{N}$ \\
\hline Asparagin & $\begin{array}{l}.35 \text { grams " } \mathrm{A} \text { " } \\
.35 \text { grams " } \mathrm{B} " \\
\ldots \ldots \ldots \ldots\end{array}$ & $\begin{array}{r}.36 \\
1.17 \\
.18\end{array}$ & $\begin{array}{c}.16 \\
.96 \\
\ldots . . . .\end{array}$ & $\begin{array}{r}.45 \\
1.84 \\
.22\end{array}$ & $\begin{array}{r}.21 \\
1.60 \\
\ldots \ldots\end{array}$ \\
\hline Water & $\begin{array}{l}.35 \text { grams " } \mathrm{A} \text { ", } \\
.35 \text { grams "B" }\end{array}$ & $\begin{array}{l}.02 \\
.03\end{array}$ & & $\begin{array}{l}.02 \\
.04\end{array}$ & \\
\hline
\end{tabular}

The amount of nitrogen in the checks is so small as to be well within experimental error. The $\mathrm{NH}_{3}$ split off by powder 
"B" would be almost negligible were the findings not so consistent. There is a definiteness about the increase over the checks that can hardly be ignored. In order to get further evidence on this point, however, another series (table xvII) was set up, using urea and asparagin in 1 per cent concentrations as substrates. The flasks were maintained at a temperature of $35^{\circ} \mathrm{C}$. for 30 days.

TABLE XVII

THE ACTION OF DEHYDRATED CHLAMYDOMONAS CELLS UPON ASPARAGIN AND UREA

\begin{tabular}{|c|c|c|c|}
\hline Substrate & $\begin{array}{l}\text { Weight } \\
\text { algal } \\
\text { powder }\end{array}$ & $\begin{array}{c}\text { Nitrogen as } \mathrm{NH}_{3} \text { split } \\
\text { off in } 30 \text { days } \\
\text { mgms. }\end{array}$ & $\begin{array}{l}\text { Net nitrogen } \\
\text { mgms. }\end{array}$ \\
\hline Asparagin & $\begin{array}{c}.5 \text { grams "A" } \\
.5 \text { grams "B" } \\
\ldots \ldots \ldots \ldots\end{array}$ & $\begin{array}{r}1.15 \\
3.10 \\
.65\end{array}$ & $\begin{array}{r}.20 \\
2.20 \\
\ldots \ldots .2\end{array}$ \\
\hline Urea & $\begin{array}{c}.5 \text { grams " } \mathrm{A} " \\
.5 \text { grams "B" } \\
\ldots \ldots \ldots \ldots \ldots \ldots \\
\end{array}$ & $\begin{array}{r}1.45 \\
3.70 \\
.98 \\
\end{array}$ & 2.47 \\
\hline Water & $\begin{array}{l}.5 \text { grams "A" } \\
.5 \text { grams "B" } \\
\end{array}$ & $\begin{array}{l}.30 \\
.25 \\
\end{array}$ & $\begin{array}{c}\cdots \cdots \cdots \cdots \\
\cdots \cdots \cdots \cdots \\
\end{array}$ \\
\hline
\end{tabular}

In this, as in table xvI, the evidence goes to show that although the desamidization is practically negligible where the alga is grown with $\left(\mathrm{NH}_{3}\right)_{2} \mathrm{SO}_{4}$ as a source of nitrogen, it is definite where the nitrogen is supplied in the amino and amido form. The actual splitting is small in any case.

On the basis of the above, we can simply reason by analogy, and yet this analogy points to the fact that the probable reason for the failure to demonstrate amidase in Ulva lies in the failure to form that enzyme. This in turn would indieate that the great growth of Ulva in sewage-contaminated waters is probably due to the abundance of desamidizing bacteria which those waters maintain-bacteria which break down the protein molecule with the ultimate setting free of $\mathrm{NH}_{3}$. Nitrogen, as such, becomes directly available to the plant.

\section{NUCLEASES}

The presence of nucleases in the algae has already been reported by Teodoresco ('12), but since he investigated only 
one of the forms falling within the scope of this study, experiments were carried on to determine the presence or absence of nucleases in one representative of each group, Olva, $\mathrm{Ce}$ ramium, and Ascophyllum.

One-half per cent nuclein was dissolved in N/10 $\mathrm{NaOH}$, the complete solution of the compound being shown by a drop of phenylphthalein. One hundred ce. of this neutral solution were added to each flask together with 3 grams of air-dried algal powder. Toluene was added as an antiseptic. Checks were set up by adding autoclaved algal powder to the nuclein and also by using nuclein solution alone. The flasks were placed at $35-36^{\circ} \mathrm{C}$. for 38 days, at the end of which time the phosphoric acid split off was determined as $\mathrm{P}_{2} \mathrm{O}_{5}$ by the uranium-acetate method. ${ }^{1}$ Five cc. of a sodium acetate solution $^{2}$ were added to $25 \mathrm{cc}$. of the nuclein substrate, this brought to a boil and titrated while hot. Potassium ferrocyanide was used as an indicator-a drop of the titration mixture being removed from time to time and brought into contact with a drop of the indicator on a porcelain plate. The results obtained are given in table xviII.

TABLE XVIII

THE ACTION OF POWDERED TISSUE FROM CERTAIN ALGAE UPON NUCLEIN

\begin{tabular}{|c|c|c|c|}
\hline $\begin{array}{l}\text { Substrate } \\
100 \text { cc. } \\
1 \text { per cent }\end{array}$ & Weight algal powder & $\begin{array}{c}\text { Free } \mathrm{H}_{8} \mathrm{PO}_{4} \text { as } \mathrm{P}_{2} \mathrm{O}_{5} \\
\text { in } 100 \mathrm{cc} \text {. in } 38 \text { days } \\
\text { mgms. }\end{array}$ & $\begin{array}{c}\text { Net amount } \\
\mathrm{P}_{2} \mathrm{O}_{5} \text { in } 100 \mathrm{cc} . \\
\text { mgms. }\end{array}$ \\
\hline Nuclein & $\left|\begin{array}{lll}3 & \text { gms. } & \text { Ceramium } \\
3 & \mathrm{gms} & \text { Ceramium boiled } \\
3 & \mathrm{gms} & \text { Ulva } \\
3 & \mathrm{gms} & \\
3 & \mathrm{gms} . & \text { Ascophyllum } \\
3 & \mathrm{gms} & \text { Ascophyllum bld. }\end{array}\right|$ & $\begin{array}{l}70.00 \\
13.75 \\
56.70 \\
17.50 \\
17.25 \\
16.90\end{array}$ & $\begin{array}{r}56.25 \\
39.20 \\
\cdots 35 \\
\ldots\end{array}$ \\
\hline
\end{tabular}

These findings substantiate those of Teodoresco ('12) regarding the general presence of nucleases in the algae. The values for Ceramium agree very well with those he obtained for the same form, i. e., 56.25 milligrams in 38 days at $35^{\circ} \mathrm{C}$., as compared with 76.6 milligrams in 51 days at $22-26^{\circ} \mathrm{C}$. Ulva

${ }^{1}$ The standard solution of the uranium acetate contained 8.8652 grams of the salt in 250 ce. of water, and each ce. by calculation was equivalent to 5 milligrams of $\mathrm{P}_{2} \mathrm{O}_{5}$.

2 The sodium acetate solution contained 25 grams of sodium acetate and 25 ce. of 30 per cent acetic acid in 250 cc. 
shows less nuclease activity than does Ceramium, while Ascophyllum, true to its reputation for inactivity, gives a value so small as to be negligible.

An interesting point is brought out by the use of nucleinone that proves a check on some of the previous proteinase experiments. Nuclein is composed of nucleic acid bound up with some protein (according to Abderhalden, ' 11 , this is albumin) which must be split off by a proteinase before the nuclein residue is exposed to the attack of the nuclease. That unmistakable nuclease activity was evident, only serves to show again the presence of proteolytic enzymes.

\section{OXIDASES AND CATALASES}

Oxidases.-Direct and indirect tests for oxidase action, that is, for the oxidases and the so-called peroxidases, were carried out in all cases with fresh tissue. The general method described by Clark ('10) was employed, using guaiacum, alpha naphthol, and phenylphthalin as reagents. Five grams of the fresh tissue, crushed with an equal weight of fine quartz sand, were extracted for half an hour with $25 \mathrm{cc}$. of distilled water. The extracting fluid was then filtered off, the tissue residue pressed out, and the filtrate made up to 50 cc. Five cc.portions were placed in test-tubes, and for the direct test, ten drops of the reagent were added; for the indirect test, this amount plus 1 cc. of fresh 3 per cent hydrogen peroxide. In only two cases was direct oxidization observable-with Agardhiella and Ulva. With the former, direct action was strong with all three reagents, and when peroxide was added an immediate deepening of the color occurred, showing the presence of peroxidases as well. With Ulva, however, both direct and indirect tests were only weakly positive. Atkins ('14), it will be remembered, obtained direct tests with but one of twenty-nine diverse algae investigated and indirect tests with but seven. He thought that reducing substances prevent the demonstration of oxidases in other forms. As brought out in the review of literature, Reed (' $15^{\mathrm{a}}$ ) has since demonstrated indirect oxidation of the alpha naphthol-paraphenylenediamine group of compounds by many of these 
forms. In the filamentous forms he showed the presence of oxidases by the formation of colored granules within the cells surrounded by these reagents. Reed concludes that oxidases of specific oxidative ability are very generally present in the algae, and where negative results are obtained, either the necessary specific compound is not present or other factors enter in, such as the destruction of the oxidase equilibrium of the cell upon crushing.

Catalases.-Both fresh and air-dried tissue were used for catalase demonstration. In a preliminary series, the addition of 5 cc. of 3 per cent hydrogen peroxide to about a gram of fresh crushed algal tissue showed evolution of oxygen in all cases except one, that of Mesogloea. Later, a series (table xix)

TABLE XIX

CATALASE ACTIVITY OF CERTAIN ALGAE

\begin{tabular}{|c|c|c|c|}
\hline \multirow{2}{*}{ Alga } & \multicolumn{3}{|c|}{ Number cc. $\mathrm{O}_{2}$ evolved at $21.5^{\circ} \mathrm{C}$. } \\
\hline & 2 minutes & 5 minutes & 10 minutes \\
\hline 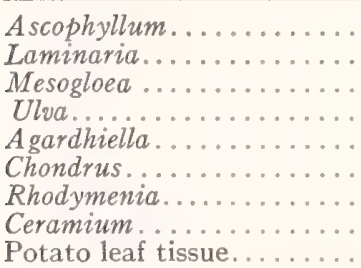 & $\begin{array}{r}.3 \\
1.4 \\
0.0 \\
.2 \\
3.3 \\
.4 \\
.9 \\
3.7 \\
22.6\end{array}$ & $\begin{array}{r}.9 \\
2.3 \\
0.0 \\
.4 \\
4.6 \\
2.0 \\
1.4 \\
5.9 \\
\cdots\end{array}$ & $\begin{array}{l}.9 \\
2.3 \\
0.0 \\
.5 \\
5.6 \\
2.5 \\
2.0 \\
8.2 \\
\cdots\end{array}$ \\
\hline
\end{tabular}

was set up in which 1 gram of powder was placed in 125 ce. Erlenmeyer flasks, 10 cc. of 3 per cent hydrogen peroxide added, and the oxygen evolved collected in a gas burette over water. The flask in which the action was taking place was shaken every 15 seconds, and the volume of oxygen evolved read at the end of 2, 5, and 10 minutes. The temperature of the room was practically constant during the experiments and no especial precautions were taken to control the temperature of the flask other than keeping the hands away from it during the action. The results are not meant to be quantitatively exact, but they do give the relative catalase activity of the several forms. In addition, air-dried potato leaf tissue that had been in the laboratory about the same length of time as the algal tissue was tested for comparison. 
Catalase, so wide-spread in all plant tissues, is found here in all the forms investigated except Mesogloea. The "reds" prove more active than the "browns," and these latter slightly more active than the "greens." No alga is strikingly active, however, when compared with potato leaf tissue. Strangely, Ulva, most active in regard to the other enzyme groups, is one of the least so here.

\section{General Discussion and Conclusions}

The data obtained in the foregoing investigation serve to show that the number of enzymes in the algae that can be isolated, by standard methods at least, is quite limited. This is especially true of the "browns," in two forms of which, Ascophyllum, and the Fucus of the earlier study, such action is limited to catalase alone. In this group the demonstrable carbohydrases are restricted to very slowly acting diastases in Laminaria; in neither Ascophyllum nor Mesogloea is there the slightest trace of what might be termed carbohydrate hydrolysis. Moreover, negative results are obtained in these forms for most of the other enzymes sought. Laminaria shows lipases and catalases (it was not tested for proteolytic or nuclease activity), and action in Mesogloea is restricted to lipases and proteinases, both tryptic and ereptic. On the other hand, very general enzymic activity is demonstrable in the "greens" and the "reds"-_diastases, dextrinases, lipases, proteinases (tryptic and ereptic), nuclease, and catalase being isolated from the crushed tissue. Oxidase is shown present in one "red," Agardhiella, and in one "green," Ulva. Such action, as a whole, appears a little more rapid in the "reds" than in the "greens," but no enzyme stands out as being specific for either a group or an alga within a group.

The carbohydrases demonstrated are restricted in their action to those hydrolysing starch, dextrin, glycogen, and laminarin of the polysaccharides used as substrates, and in Laminaria, such action was further limited by a failure to act upon glycogen. In no case, in any member of the three groups was there evidence of disaccharides being attacked. While 
this is not so surprising perhaps for sucrose and lactose, it is difficult to understand the failure of enzymic hydrolysis of maltose. The results obtained by Kylin ('13) indicate that both dextrose and fructose are found in algal tissues, and reasoning from results found for plant and animal cissues in general, it seems, as is true in those cases, that in the algae, maltose must be broken down to glucose before assimilation can take place. The failure to isolate this enzyme points to the possible presence of some inhibiting factor, rather than to the non-formation of the ferment.

Lipases, acting very slowly, appear wide-spread in algae, being demonstrable in all the forms used in this study excepting Ascophyllum. Along with the fact that fats are very generally found in the algae, these results are significant in that they indicate the importance of the rôle these compounds may play as assimilatory products. It is not thought, as was advanced by Reinke ('76), Hansen ('93), and others, that these fats function as the first products of assimilation, but rather, that they act as storage products of more or less importance.

The algae, in general, show the presence of enzymes capable of hydrolysing certain proteins. Casein and peptone in alkaline and neutral solution prove the most favorable substrates of those tested, although legumin and albumin are also slightly attacked. The "greens" and the "reds" are about equally active in this way, the "browns," as usual, acting more slowly. The fact that both native proteins and peptones were hydrolysed, points to the presence of both tryptic and ereptic enzymes. Still further evidence of the presence of the first of these was the splitting of the protein molecule from nuclein preceding the action of nuclease.

Amidases seem not to be formed by any of these algae. The results obtained with Chlamydomonas, from which the amidases were isolated when the alga was grown on a medium containing asparagin and peptone as a source of nitrogen but not when the nitrogen was in the form of ammonium sulphate, indicate that such amidase formation may depend upon the nature of the supply of assimilable organic nitrogen. This has a distinct bearing upon the reason for the increased growth of 
Ulva in sewage-contaminated waters. In order to break down the proteins present in the surrounding waters and even those in close contact with the plant itself, it would be necessary for the Ulva to secrete an extracellular enzyme, since the large protein molecule is not diffusible into the cell. If so secreted, the enzyme would be quickly dissipated in the large volume of surrounding water. Desamidizing bacteria, on the other hand, have been demonstrated in harbor and shore waters where such algae abound. They can come into much more intimate contact with the protein than can the plant, and undoubtedly play an important rôle in rendering available at all times an abundant supply of organic nitrogen.

The demonstration of nucleases acting upon the previously split nuclein molecule, substantiates the findings of Teodoresco for this enzyme. Both Ulva and Ceramium showed the presence of the ferment, while Ascophyllum, the only representative of the "browns" investigated, gave negative results. Where such enzymes were formed, they compared more favorably with enzymes of fungi and higher plants than do any of the other algal ferments.

None of the "browns" studied showed the presence of oxidative enzymes, while in the "reds" and the "greens" but one form gave the characteristic reactions. It is interesting to note that these algae, Agardhiella and Ulva, were the most enzymatically active forms studied. The oxidase reactions with guaiacum, alpha naphthol, and phenylphthalin were very positive, both directly, and indirectly with hydrogen peroxide.

In all cases where enzymes were demonstrated, the action was very slow, being with the exception of nuclease, much less rapid than in the higher plants. The reason for this is not clear, but it cannot in all instances be due to inhibiting substances set free upon the death of the cell. Arber ('01), as has been mentioned before, found that Ulva, Cladophora, and Enteromorpha, placed in the dark but under otherwise presumably normal conditions, required from two weeks with Ulva, to two months and more in the case of Enteromorpha for destarching. This indicates the presence of a very slowly acting diastase in the cells of these algae. The metabolism 
of the algae is also probably slower than that of the higher plants and one might expect, a priori, the enzymes also to be less rapid in their action. Although the algal enzymes may be inherently slow, it seems that there may also be substances set free on the death of the cell which either partially or entirely inhibit enzyme action. The writer has found evidence in some preliminary experiments, that the action of taka diastase upon starch is directly proportional to the amount of free tannin present. In connection with this, it was also found that Ascophyllum had a "tannoidal" content of 1.1 per cent of the dry weight. It is possible that such tannoids, if in an uncombined state, may after the death of the cell unite with an enzyme to throw it out of the sphere of action. That diastases are demonstrable in tissues having a high tannin content may perhaps be explained on the basis that they are bound up in such a way as to render them incapable of uniting with the ferments. Still other organic inhibiting compounds may be present, and the point opens up a very interesting problem concerning inhibition, not only in algal tissues, but in those of many higher plants as well.

\section{Summary}

1. Using standard methods of enzyme isolation and determination, the following enzymes have been found in fresh or dried algal tissue:

a. Carbohydrases hydrolysing the polysaccharides, starch, dextrin, glycogen, and laminarin, but not those hydrolysing the several disaccharides employed as substrates.

b. Lipases acting upon neutral fats but not upon the esters of the lower fatty acids.

c. Proteinases (tryptic and ereptic) acting best under neutral and alkaline conditions.

d. Nucleases.

e. Oxidases and peroxidases (in but two forms-Agardhiella and Ulva).

f. Catalases. 
2. Negative results were obtained for cellulase, cytase, maltase, lactase, sucrase, amidase, and esterase.

3. The action of all the enzymes isolated was very slow.

It is a pleasant duty to acknowledge indebtedness to those who in various ways have lent support to this investigation. Such acknowledgments are due Dr. George T. Moore for the privileges of the Missouri Botanical Garden, especially its library and laboratories; to Dr. Benjamin M. Duggar, at whose suggestion the problem was undertaken, and under whose direction and constant kindly interest it has been pursued; to Dr. Phillip A. Shaffer, of the Biochemical Laboratories of the Washington University Medical School, for suggestions and advice concerning biochemical methods, and for the courtesy of his laboratory from time to time; and finally, to the Woods Hole Biological Laboratory, for the privileges extended during the summers of 1913-14.

Graduate Laboratory, Missouri Botanical Garden.

\section{BiBLIOGRAPHY}

Abderhalden, E. ('11). Text-book of physiological chemistry. 1911.

Albert, R., Buchner, E., und Rapp, R. ('02). Herstellung von Dauer-Hefe mittels Acetone. Ber. d. deut. chem. Ges. 35:2376-2382. 1902 .

Arber, E. A. N. ('01). On the effect of salts on the assimilation of carbon-dioxide in Ulva latissima. Ann. Bot. 15:39-69. 1901. algae. Ibid. 15:669-681. 1901 .

Artari, A. ('13). Zur physiologie der Chlamydomonaden. Jahrb. f. wiss. Bot. 52:410-466. $p l .6 .1913$.

Atkins, W. R. G. ('14). Oxidases and their inhibitors in plant tissues. III. The localization of oxidases and catalases in some marine algae. Dublin Roy. Soc., Scientif. Proc. 14:199-206. 1914.

Bartholemew, E. T. ('14). Concerning the presence of diastase in certain red algae. Bot. Gaz. 57:136-147. 1914.

Bauer, R. W. ('89). Ueber ein aus Laminariaschleim entstehende Zuckerart. Ber. d. deut. chem. Ges, 22:618, 1889.

Baur, E. ('02). Über zwei denitrificirende Bakterien aus der Ostsee. Wiss. Meeresunters. N. F. Abt. Kiel 6: 9-21. pl. 1. 1902.

Bayliss, W. M. ('14). The nature of enzyme action. 1914.

Benecke, W., und Keutner, J. ('03). Ueber Stickstoffbindende Bakterien aus der Ostsee. Ber. d. deut. bot. Ges. 21:333-346. 1903. 
Beyerinck, M. W. ('90). Cultureversuche mit Zoochlorellen, Lichenengonidien, und anderen niederen Algen. Bot. Zeit, 48:726-.36, pl. 7, f. 1-5. 1890.

, $\left({ }^{\prime} 04\right)$. Chlorella variegata, ein bunter Mikrobe. Rec. trav. bot. Neerlandais. 1:14-27. 1904.

Bloor, W. R. ('14). A method for the determination of fat in small amounts in blood. Jour. Biol. Chem. 17:377-384. 1914.

Bourquelot, E., et Herissey, H. ('99). Germination de Ia graine de Caroubier; production de mannose par un ferment soluble. Compt. Rend. Acad. Paris $129: 614-616.1899$.

Brandt, K. ('99). Über den Stoffwechsel in Meere. Wiss. Meeresunters. N. F. Abt. Kiel 4:215-230. 1899.

Bruns, E. ('94). Ủber die Inhaltkörper der Meeresalgen. Flora 79:159-178. pl.6. 1894 .

Bütschli, O. ('03). Notiz ueber die sogenanute Florideen Stårke. Verh. Naturf. Med. Ver. Heidelberg. N. F. 7:519-528. 1903. [cited from Bartholemew '14.]

Charpentier, P. G. ('02). Sur l'assimilation du carbone par une algue verte. Compt. Rend. Acad. Paris 134:671-673. 1902.

- ('03). Alimentation azotée d'une algue, le Cystococcus humicola. Ann. Inst. Pasteur. 17:321-334. 1903.

- ('03a). Recherches sur la physiologie d'une algue verte. Ibid. 17:369420. 1903 .

Chick, H. ('03). A study of a unicellular green alga occurring in polluted water, with special reference to its nitrogen metabolism. Roy. Soc. London, Proc. 71:458-477. 1903.

Clark, E. D. ('10). The plant oxidases. Dissertation, Columbia Univ. 1910. 1911 .

('11). A study of Lintner soluble starch. Biochem. Bul. 1:194-296.

Cooley, J. S. ('14). A study of the physiological relations of Sclerotina cinerea (Bon.) Schröter. Ann. Mo. Bot. Gard. 1:291-326. 1914.

Cross, C. F., Bevan, E. J., and Smith, C. ('95). Ueber einige chemische Vorgänge in der Gerstenpflanzen. Ber. d. deut. chem. Ges. 28:2604-2609. 1895.

Crato, E. ('92). Die Physode, ein Organ des Zellenleibes. Ber. d. deut. bot. Ges. 10:295-302. f. 1-8. 1892 .

1892, ('93). Ueber die Hansteen'chen Fucosankörner. Ibid. 11:235-241.

('93a). Morphologische und mikrochemische Untersuchungen ueber die Physoden. Bot. Zeit. 51': 157-195. 1893.

Czapek, F. ('13). Biochemie der Pflanzen. 1:pp. 760-761. 1913.

Dox, A. W. ('10). The intracellular enzymes of Penicillium and Aspergillus. U. S. Dept. Agr., Bur. Animal Ind., Bul. 120: 1-70. 1910.

Duggar, B. M., and Davis, A. R. ('14). Enzyme action in Fucus vesiculosus. Ann. Mo. Bot. Gard. 1:419-426. 1914.

Emmerling, O. ('02). Über die Eiweissspaltung durch Papayotin. Ber. d. deut. chem. Ges. 35:695-699. 1902.

Euler, H. ('12). General chemistry of the enzymes. 1912. 
Famintzin, A. ('67). Die Wirkungs des Lichtes auf Spirogyra. Acad. Imp. d. Sci. de St. Petersbourg, Mélanges biol. 6:277. 1867. [cited from Oltmanns, '05.]

Fischer, A. ('05). Die Zelle der Cyanophyceen. Bot. Zeit. 63:51-129. pl. 4-5, f. 1-64. 1905 .

Folin, O., and Farmer, C. J. ('12). A new method for the determination of total nitrogen in urine. Jour. Biol. Chem. 11:493-501. 1912.

Foster, G. L. ('14). Indications regarding the source of combined nitrogen for Ulva lactuca. Ann. Mo. Bot. Gard. 1:229-235. 1914.

Fowler, G. J. ('11). An introduction to bacteriological and enzyme chemistry. p. 159. 1911.

Gran, H. H. ('02). Studien ueber Meeresbakterien I. Bergens Mus. Aarbog $1901^{10}: 1-23.1902$.

('02a). Die Hydrolyse des Agars durch ein Enzyme. Centralbl. f. Bakt. II. $9: 562-563$. 1902 .

Green, J. R. ('99). The soluble ferments and fermentation. 1899.

Greenish, H. ('81). Untersuchung von Fucus amylaceus. Pharm. Zeitschr. f. Russl. 20:501-507. 1881. [Ber. d. deut. chem. Ges. 14:2253. 1881.]

('82). Die Kohlenhydrate des Fucus amylaceus. Archiv Pharm. 17: 241-257, 321-335. 1882. [Ber. d. deut. chem. Ges. 15:2243-2244. 1882.]

Grüss, J. ('02). Ueber den Umsatz bei der Keimung der Dattel. Ber. d. deut. bot. Ges. 20:36-44. 1902 .

('10). Ueber das Verhalten von Cytase und Cytokoagulase bei der Gummibildung. Jahrb. f. wiss. Bot. 47:393-429. pl. 13, f. 1-3. 1910.

Guignard, L. ('92). Observations sur l'appareil mucifère des Laminariacées. Ann. d. Sei. Nat., Bot. VII. 15:1-46. f. 1-20. 1892.

Günther, A., und Tollens, B. ('90). Über die Fucose, einen der Rhamnose isomeren Zucker aus Seetang (Fucus-arten). Ber. d. deut. chem. Ges, 23:2585-2586. 1890.

Hansen, A. ('93). Ueber Stoffbildung bei den Meeresalgen. Mitth. aus d. Zool. Sta. zu Neapel 11. Berlin, 1893. [cited from Kylin '13.]

Hansteen, B. ('92). Studien zur Anatomie und Physiologie der Fucoideen. Jahrb. f. wiss. Bot. 24:317-362. pl. $\gamma-10, f .1-30.1892$.

('00). Ueber das Fucosan als erstes scheinbares Product der Kohlensauireassimilation bei den Fucoideen. Ibid. 35:611-625. pl. 14, f. 1-11. 1900 .

Hauptfleisch, ('88). Zellmembran und Hüllgallerte der Desmidaceen. Dissertation. Greifswald, 1888. [cited from Walliczek '93.]

Hérissey, H. ('03). Recherches chimiques et physiologiques sur le digestion des mannanes et des galactanes par la seminase, chez les végétaux. Rev. Gén. Bot. 15:345-368, 369-392, 406-417, 444-464. 1903.

Hunger, F. W. T. ('02). Ueber das Assimilationprodukt der Dictyotaceen. Jahrb. f. wiss. Bot. 38:70-82. 1902 .

Klebs, G. ('84). Ueber die Organisation der Gallerte bei einigen Algen und Flagellaten. Bot. Inst. Tübingen, Arb. 2:p. 333. 1884.

('85). Ueber Bewegung und Schleimbildung der Desmidaceen. Biol. Centralbl. 5:353-367. 1885. 

Jena, 1896.

Koenig, J. und Bettels, J. ('05). Die Kohlenhydraten der Meeresalgen und daraus hergestellter Erzengnisse. Zeitschr. f. Untersuch. d. Nahrungs- und Genussmittel 10:457-473. 1905 .

Kolkwitz, R. ('00). Beiträge zur Biologie der Florideen. Wiss. Meeresunters. N. F. Abt. Helgoland, Kiel, und Leipzig 4:31-62. f. 1-\%. 1900.

Krause, G. ('70). Einige Beobachtungen ueber den Einfluss des Lichtes und der Warme auf der Stäke Erzeugung im Chlorophyll. Jahrb. f. wiss. Bot. 7 : 511-531. $p l$. 24, f. 1-4. 1870.

Krefting, A. ('97). Ueber wictige organische Produkt aus Tang. Chem. Ind. 1897. No. 20. [Just's bot. Jahresber. 25²:76. 1897.]

- und Torup, S. ('09). Et nyt Kulhydrat i Laminariaarterne. Tidskrift f. Kemi, Farmaci, og Terapi, Aarg. 6, Kristiania 1909. [cited from Kylin, '15.]

Kiister, E. ('89). Ueber Derbesia und Bryopsis. Ber. d. deut. bot. Ges, 17:77-84. pl. $6, f .1-8.1889$.

Kylin, H. ('12). Ueber die Inhaltskorper der Fucoideen. Arkiv f. Bot. 115:1-26. pl. 1. 1912 .

('13). Zur Biochemie der Meeresalgen. Zeitschr. f. physiol. chem. 83: 171-197. 1913.

('15). Untersuchungen über die Biochemie der Meeresalgen. Ibid. 94: $337-425.1915$.

Leitgeb, H. ('87). Die Inkrustation der Membran von Acetabularia. Sitzungsber. d. k. Akad. d. Wiss., Wien, math.- naturw. Kl. 1887 : p. 96.1887.

Letts, E. A., and Hawthorne, J. ('00). The seaweed Ulva latissima and its relation to the pollution of seawater by sewage. Brit. Assoc. Adv. Sci., Rept. 1900:935-936. 1900.

$\longrightarrow,($, 01$)$. On the absorption of ammonia from polluted sea water by the Ulva Iatissima. Ibid. 1901:831-833. 1901.

— and Richards, E. H. ('11). On green seaweeds (especially Ulva latissima) in relation to the pollution of waters in which they occur. Seventh Report Roy. Comm. on Sewage Disposal, Appendix 3:72-100. 1911.

Meyer, A. ('95). Untersuchungen ueber die Stärkekörner, Jena, 1895.

Miither, A., und Tollens, B. ('04). Ueber die Produkt der Hydrolyse von Seetang (Fucus), Laminaria, und Caragheen Moos. Ber. d. deut. chem. Ges. 37: 298-305. 1904.

Nägeli, C. ('63). Sphärokrystalle in Acetabularia. Nägeli's Bot. Mitth. 1:206213. $p l$. 1. 1863 .

Oshima, K., und Tollens, B. ('01). Ueber das Nori aus Japan. Ber. d. deut. chem. Ges. 34:1422-1424. 1901.

OItmanns, F. ('04). Morphologie und Biologie der Algen 1:p. 76.1904.

— ( $\left({ }^{\circ} 05\right)$. Ibid. 2:pp. 147-164. 1905.

Ravenna and Cereser, ('09). Origin and physiological function of pentosans in plants. Jour. Lond. Chem. Soc. 96:1946. 1909. [cited from Swartz '11.]

Reed, G. M. ('15). Studies in plant oxidases (Preliminary report). Science N. S. $41: 175.1915$.

- ('15a). Evidences for the general distribution of oxidases in plants. Bot. Gaz. 59:407-409. 1915. 
Reed, H. S. ('12). The enzyme activities involved in certain fruit diseases. Va. Agr. Exp. Sta., Ann. Rept. 1911-1912:51-77. 1912.

Reinke, J. ('76). Beitrïge zur Kenntniss der Tange. Jahrb. f. wiss. Bot. 10:317381. pl. 25-27, f. 1-18. 1876.

('03). Die zur Ernährung der Meeresorganismen disponiblen Quellen an Stickstoff. Ber. d. deut. bot. Ges. 21:371-380, 1903.

Saiki, T. ('06). The digestibility and utilization of some polysaccharide carbohydrates derived from lichens and marine algae. Jour. Biol. Chem. 2:25l265. 1906 .

Schmiedeberg, ('85). Ueber der Bestandtheile der Laminaria. Tageblatt der 58th. Versammlung deutscher Naturforscher und Ärzte in Strassburg. 1885. [cited from Swartz' 11.]

Schmitz, Fr. ('83). Die Chromatophoren der Algen. Verhandl. d. naturh. Ver. d. preuss. Rheinlander u. Westfalens 40:—_. [cited from Kylin.]

Schöne und Tollens, B. ('92). Untersuchungen ueber Kohlenhydrate. Landw. Versuchssta, 40:377- - 1892.

Schramm, J. R. ('14). Some pure culture methods in the algae. Ann. Mo. Bot. Gard. 1:23-45. 1914.

, ('14a). A contribution to our knowledge of the relation of grass-green algae to elementary nitrogen. Ibid. 1:157-184. pl. 3. f. 1. 1914.

Sebor, J. ('00). Ueber die Kohlenhydrate des Caragheen-Moos, Oestereichische Chemiker-Zeitung. Jahrgang III: p. 441. 1900. [Bot. Centralbl. 86: p. 70. 1901.]

Senft, E. ('04). Ueber den mikrochemischen Zuckernachweis durch Phenylhydrazin. Sitzungsber. d. k. Akad. d. Wiss., Wien, math.- naturw. K1. 113: 3-27. pl. 1-2. 1904.

Shaffer, P. A. ('14). On the determination of sugar in blood. Jour. Biol. Chem. $19: 285-295.1914$.

Sörenson, S. P. L. ('08). Enzymestudien. Biochem. Zeitschr. 7:45-101. 1908.

Spargo, M. W. ('13). The genus Chlamydomonas. Washington Univ. Stud. 1: 65-88. $p l .1, f .1-1 \% .1913$.

Stenhouse, J. ('84). Ueber das Vorkommen von Mannit in Laminaria saccharina und einigen anderen Seegrassern. Liebig's Annalen der Chemie 1884:51. [cited from Swartz'11.]

Swartz, M. D. ('11). Nutrition investigations on the carbohydrates of lichens, algae, and related substances, Conn. Acad. Arts and Sci., Trans. 16:247-382. 1911.

Teodoresco, E. C. ('12). Assimilation de l'azotée et du phosphore nuclêique par les algues inférieures. Compt. Rend. Acad. Paris 155:300-303. 1912. 1912.

Tihomirov, W. A. ('10). Sur la valeur de la réaction microchemique de la phénylhydrazine pour la constatation du sucre dans les tissues des plantes. Ann. Jard. bot. Buitenzorg, Suppl. $3^{2}: 536-582$, pl. 13-15. 1910.

Timberlake, H. G. ('01). Starch formation in Hydrodictyon utriculatum. Ann. Bot. 15:619-634. pl. 34, f. 1-31. 1901. 
Torup, S. ('09). Ein neues Kohlenhydrate bei den Laminariaceen. 'Tidskrift f. Kemi, Farmaci, og Terapi, Christiania. 1909. [Biochem. Centralbl. 8:770. 1909.]

Tschirsch, A. ('89). Angewandte Pflanzenanatomie. pp. 193-217. 1889.

Vines, S. H. ('97). The proteolytic enzyme of Nepenthes. Ann. Bot. 11:563-584. 1897.

Walliczek, H. ('93). Studien ueber die membranschleime vegetativen Organe. Jahrb. f. wiss. Bot. 25:209-277. pl. 11-18, f. 1-22. 1893.

Zaleski, W. ('07). Ueber den Umsatz der Nucleinsïure in keimenden Samen. Ber. d. deut. bot. Ges. 25:349-356. 1907. 






\section{QK565. N3 York Botanical Garden Library}

Davis .D3 3 gen

|| || || || ||| || || ||| | || || || || || || ||| || || |||||

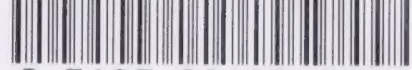

35185001072527 


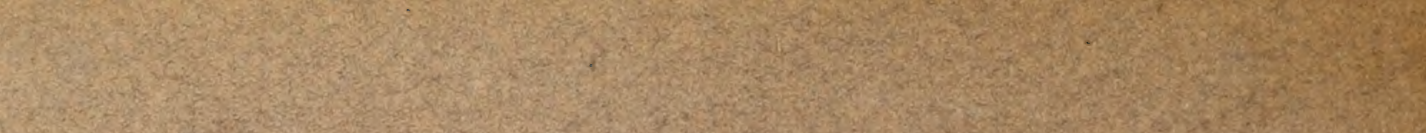
W.

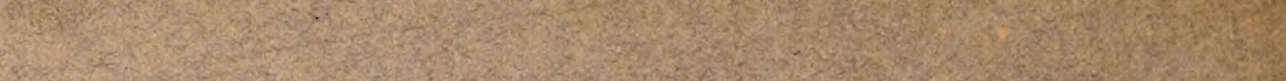

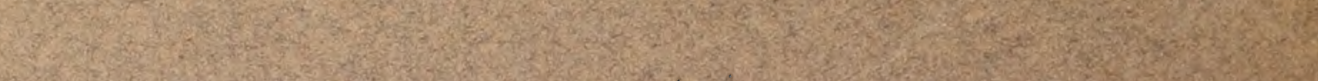

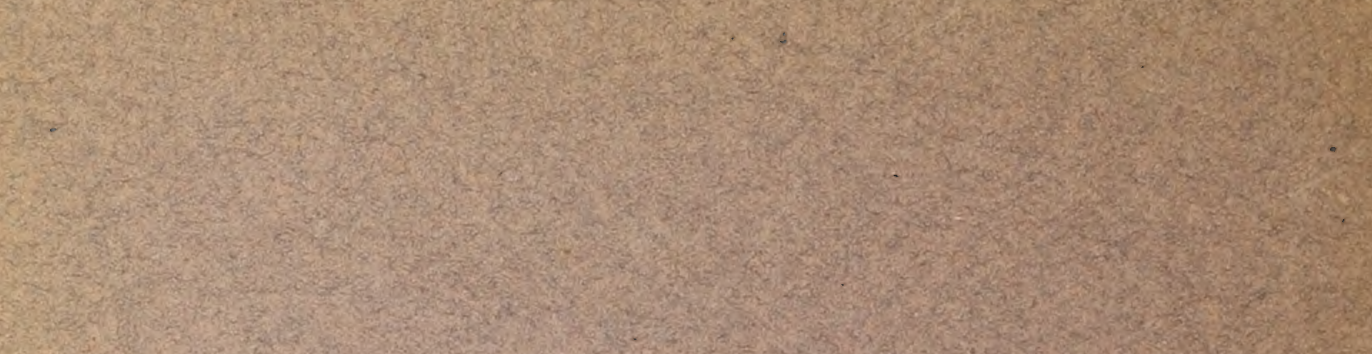

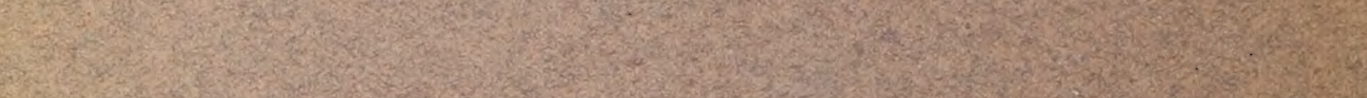

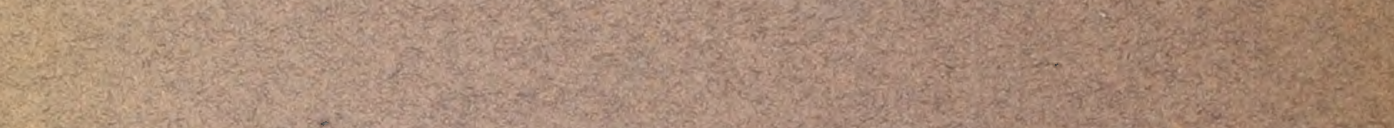

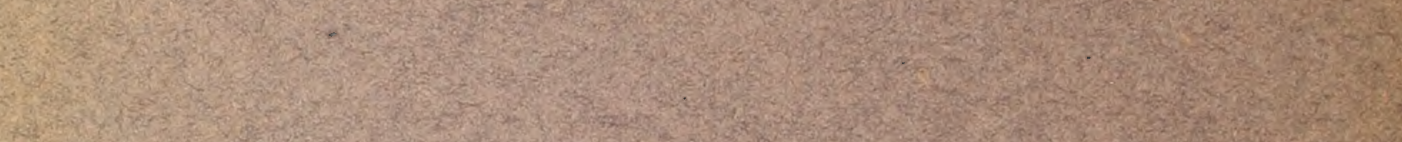

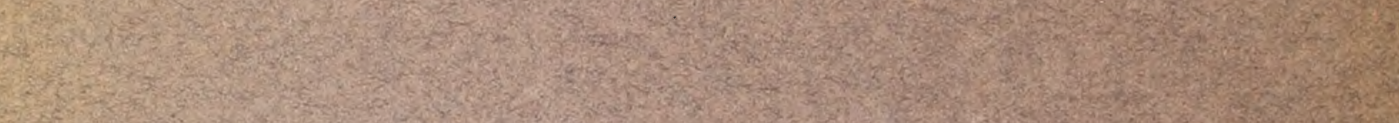

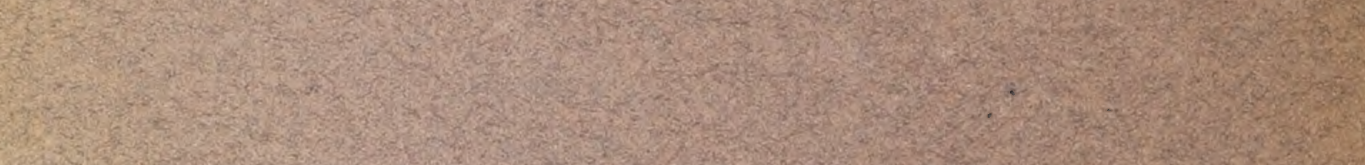
2.7.

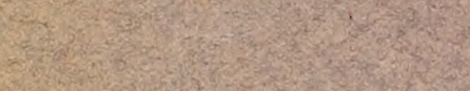
(6) (2)

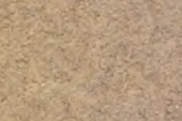

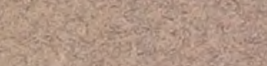
Q (x) nots

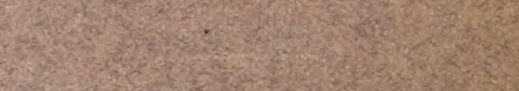

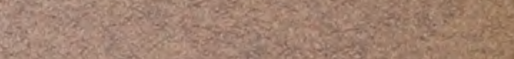

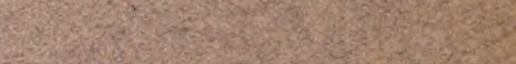

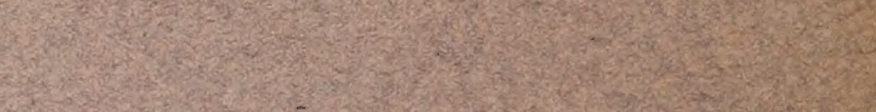

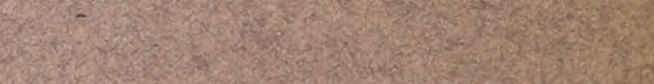

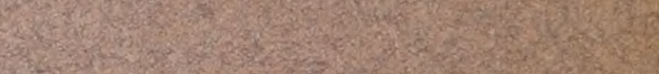
(18) (2)

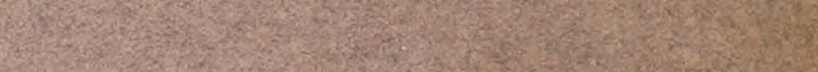
W.

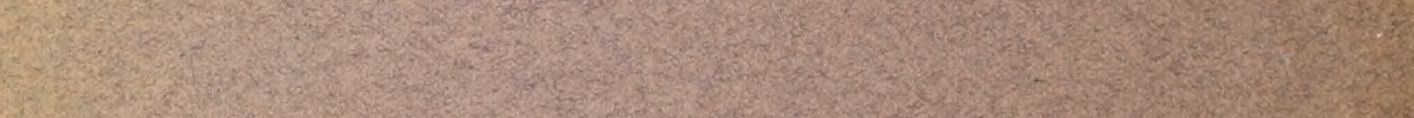
3.

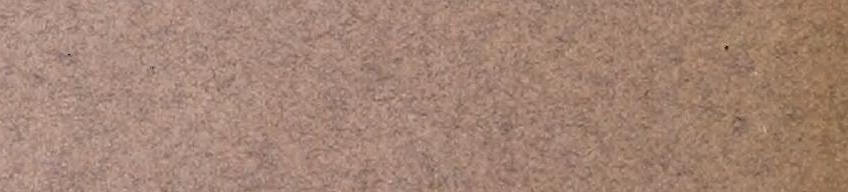

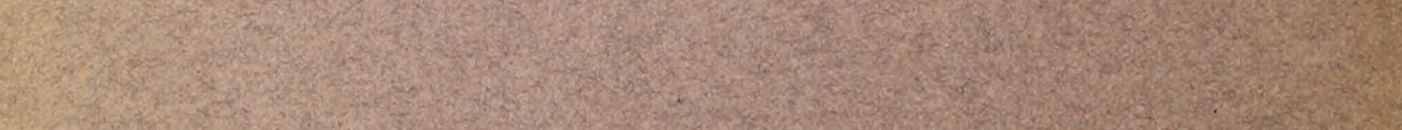

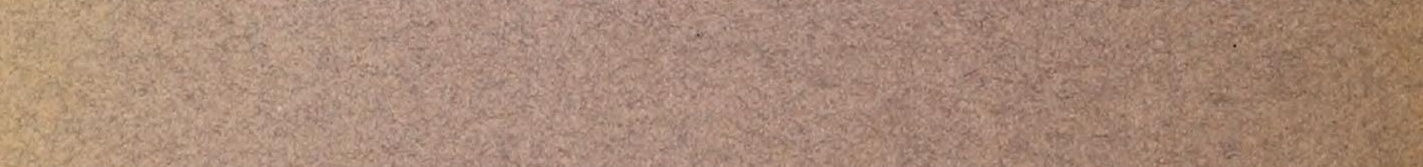

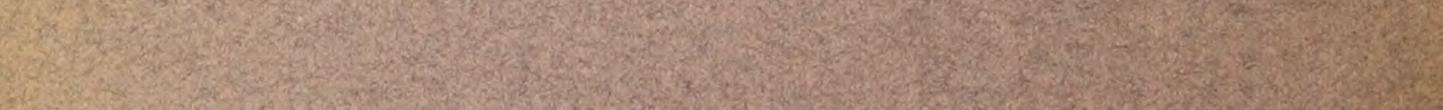

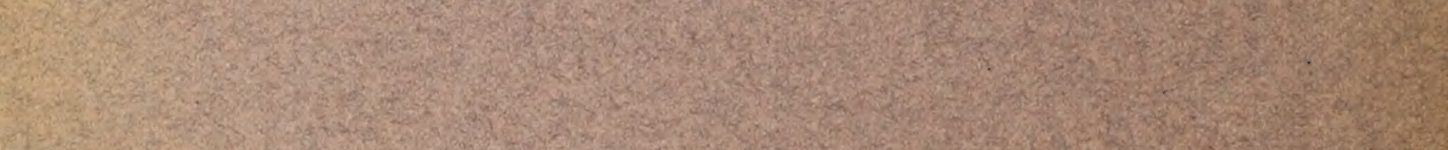
(B) 3. Q 